\title{
2. INTRODUCTION, OBJECTIVES, AND PRINCIPAL RESULTS OF DEEP SEA DRILLING PROJECT LEG 96 ${ }^{1}$
}

\author{
A. H. Bouma, Chevron Oil Field Research Company \\ J. M. Coleman, Louisiana State University \\ and \\ A. W. Meyer, Ocean Drilling Program²
}

\begin{abstract}
The Mississippi Fan is a broad, arcuate accumulation of Pleistocene deep-water sediments deposited in the eastern Gulf of Mexico. Multiple acoustical sub-bottom reflectors can be traced regionally across the entire fan, dividing this sediment body into sediment packages called fan lobes. Seven of these acoustical reflectors have been mapped and they divide the fan into seven fan lobes. Structure and isopach maps of these fan lobes reveal a general shift during the Pleistocene from west to east and toward deeper water. Each fan lobe is basically a channel-overbank complex with differing morphology and channel characteristics that allow it to be divided into upper, middle, and lower fan physiographic regions.

The upper fan region of the modern fan lobe connects to the Mississippi Canyon and is characterized by a nearly filled, large erosional channel with broad levees. A smaller, central channel is cut into the large channel fill.

The middle fan region starts near the major break in slope. It is convex in cross section with a sinuous channel at its apex. The size of the channel as well as its sinuosity decrease downfan. An acoustical high-amplitude zone near the base of the channel fill coincides with coarse-grained material.

The lower fan region starts where the single sinuous channel pattern changes into a set of near-parallel surface images, interpreted to be former channel courses. Only one channel was active at a given time and its life span was geologically short before it shifted to a new position. At the distal end, these channels may bifurcate before becoming unrecognizable on high-resolution seismic records and sediment deposition changes from a confined to an unconfined mode. The latter is characterized by sheet-sand deposition containing a significant amount of sand that originated from upper slope and shelf environments.

Major objectives for drilling the Mississippi Fan were to place the fan lobes into a time-stratigraphic framework, to determine if the midfan channel is migratory in nature, to establish the lithological characteristics of the acoustical high-amplitude zone present near the bottom of the channel fill, to analyze if sand is transported to the lower fan and in which depositional mode it is emplaced, to confirm or modify existing fan models, and to determine the physical and chemical characteristics of these deep-sea fan deposits.

Nine sites were occupied on the Mississippi Fan, four (Sites 621, 622, 617, and 620) on the middle fan, four (Sites $623,624,615$, and 614 ) on the lower fan, and one (Site 616) on the flank of the youngest fan lobe and within a surface slump deposit. Most of the holes penetrated only the youngest fan lobe.

In addition to these nine sites, two sites (618 and 619) were occupied on the continental slope off Louisiana in intraslope basins formed as the result of active salt diapirism. Orca Basin (Site 618), characterized by a 200-m-thick anoxic, high salinity layer of bottom water, was expected to provide a complete upper Neogene stratigraphical and chemical record. However, this site contained a large slump in the upper part of the drill hole. Pigmy Basin (Site 619), having normal oceanic water, contains a number of seismic facies sequences that could be related to the recovered stratigraphic section. The overall lithology of the intraslope basin sediments was very fine grained.
\end{abstract}

\section{INTRODUCTION TO SUBMARINE FANS}

Research on modern submarine canyons was spearheaded by F. P. Shepard beginning in the 1930s, and numerous studies have been completed by him and his students since that time (e.g., Shepard and Dill, 1966; Shepard and Marshall, 1969; Shepard, 1973). Independently, scientists were studying outcropping rock formations thought to represent deep-water sediments deposited by turbidity currents that originated in shallow marine settings (Kuenen and Migliorini, 1951). These initial studies, both of modern sediments and ancient

\footnotetext{
${ }^{1}$ Bouma, A. H., Coleman, J. M., Meyer, A. W., et al., Init. Repts. DSDP, 96: Washington (U.S. Govt. Printing Office).

2 Addresses: (Bouma) Chevron Oil Field Research Company, P.O. Box 36506, Houston, TX 77236; (Coleman) Coastal Studies Institute, Louisiana State University, Baton Rouge, LA 70803; (Meyer) Ocean Drilling Program, 500 University Drive West, Texas A\&M University, College Station, TX 77843
}

rocks, created an avalanche of other investigations such as those summarized in Bouma and Brouwer (1964).

Early studies on modern deep-sea depositional systems dealt primarily with descriptions of surface morphology based on echo-sounding data and of surficial sediments from gravity and piston cores (e.g., Menard, 1955; Gorsline and Emery, 1959). The first submarine fan interpretation from ancient rocks was suggested by Sullwold (1960) in his description of the late Miocene deposits in the Santa Monica Mountains, California. Later studies, such as those by Hand and Emery (1964) and Barlow (1966), led to the recognition of various turbidite facies within submarine deposits.

The first general deep-sea fan depositional model based on investigations of modern sediments was suggested by Normark (1970). He defined three distinctive morphologic regions on deep-sea fans: (1) the upper fan characterized by leveed valleys, (2) the middle fan with numer- 
ous channel bifurcations and an area of sand deposition (suprafan), and (3) the lower fan which is an area free of any major topographic relief. This initial model established the major subdivisions of submarine fan systems that has provided the basis for later models of submarine fans.

Following the Normark (1970) study, Mutti and Ricci Lucchi (1972) published a fan depositional model based on their studies of ancient turbidite sequences in the Italian Apennines. Their model elaborated on the lithological characteristics of the fan deposits, using Normark's model as a basis. Because Mutti and Ricci Lucchi could not characterize their deposits by morphologic characteristics, they instead divided ancient submarine fans into five distinct sedimentary facies: slope, inner fan, middle fan, outer fan, and basin plain.

The somewhat similar models of Sullwold (1960) and Mutti and Ricci Lucchi (1972) were followed by numerous other studies, most of which were aimed at refining the earlier models (e.g., Walker and Mutti, 1973; Normark, 1978; Walker, 1978, 1980; Shanmugam and Moiola, 1982). It was generally recognized that no single model can be universally applied to all modern fans, ancient turbidite sequences, or comparisons of modern and ancient systems. To more fully characterize modern fan systems and enhance comparisons with ancient turbidite sequences, Normark (1980) emphasized that studies of modern fan systems should include deep coring in conjunction with extensive side-scan sonar, multibeam echosounding, and seismic reflection surveys. Although these types of geophysical studies have been conducted on the Rhone Fan (Bellaiche et al., 1981; Cremer, 1983), the Amazon Fan (Damuth et al., 1983) and the Mississippi Fan (Garrison et al., 1982), the Mississippi Fan is the only modern submarine fan that has been drilled to date in a systematic manner.

Research on the Mississippi Canyon and Fan has been primarily motivated by two major programs: (1) preparation for drilling during Leg 96 of the Deep Sea Drilling Project by the Glomar Challenger in late 1983 and (2) exploration activity by the petroleum industry for hydrocarbons in the deep water facies of the Cenozoic Gulf Coast depocenter, specifically in Plio-Pleistocene sequences. A pre-existing seismic data set, augmented by a site survey conducted by Lamont-Doherty Geological Observatory (Kastens and Shor, 1985), permitted a comprehensive study of the fan prior to drilling. Mississippi Fan drilling strategies were discussed by a group of international experts (COMFAN: Committee on Fans) meeting on modern submarine fans and ancient turbidite sequences (Normark et al., 1983/84). Preliminary Mississippi Fan drilling results have been reported in Bouma, Coleman, and Meyer (1984), Bouma, Coleman, and Leg 96 Scientific Crew (1984), and in Bouma, Normark, et al. (1985).

The Mississippi Fan covers an area in excess of 300,000 $\mathrm{km}^{2}$ (Fig. 1) and has a volume of about $290,000 \mathrm{~km}^{3}$ (Stuart and Caughey, 1976; Moore et al., 1978, 1979). Its internal seismic structure and the surface morphological characteristics of the youngest fan lobe vary across the fan and are described briefly here.

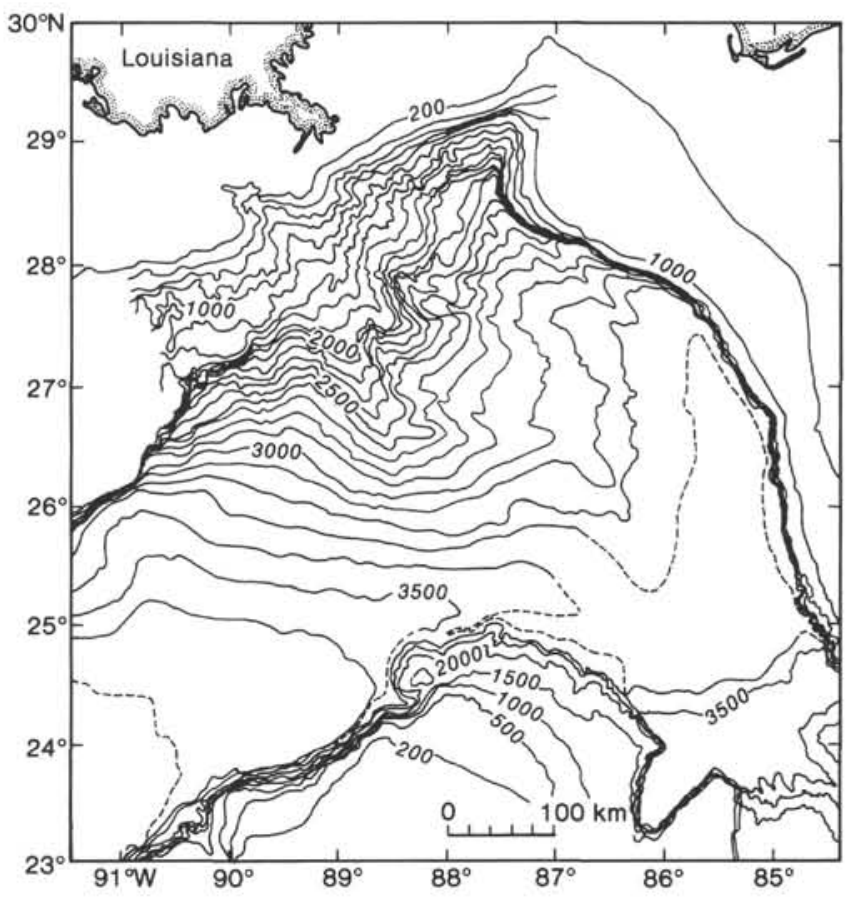

Figure 1. Simplified bathymetric map of the eastern Gulf of Mexico showing the Mississippi Fan. Contour interval in meters.

The Mississippi Fan is a large open-ocean deep-sea fan deposited in a passive margin setting, which means that its growth was not strongly influenced by basin dimensions but more by large quantities of source material with a low sand/clay ratio, and by sea level changes. The general model of sediment distribution and depositional processes may be applicable to many passive margin submarine fans but may not be applicable directly to fans developed in other settings (Normark et al., this volume).

\section{LEG 96 DRILLING PROGRAM}

Leg 96 of Deep Sea Drilling Project started on September 29, 1983 in Ft. Lauderdale, Florida and ended in Mobile, Alabama on November 8, 1983. The drilling program of the Glomar Challenger can be divided into six groups of sites: middle Mississippi Fan channel sites (621 and 622) and overbank sites (617 and 620), upper lower Mississippi Fan sites in the region of switching channels (Sites 623 and 624), lower Mississippi Fan sites where the channels terminate (Sites 614 and 615), a site in the slump area overlying the flank of the youngest fan lobe (Site 616), and intraslope basin sites (Sites 618 and 619) (Fig. 2, Table 1).

Weather and currents strongly influenced the order in which the proposed sites were drilled (Bouma, Coleman, et al., 1985). As a consequence, chronological site numbering does not reflect any geologic transects across the Mississippi Fan and the intraslope basins. For these reasons, the site chapter organization does not follow the conventional chronological order normally used in the Initial Reports, but preserves a more logical arrangement related to the construction of the fan (see Explanatory Notes, this volume). 


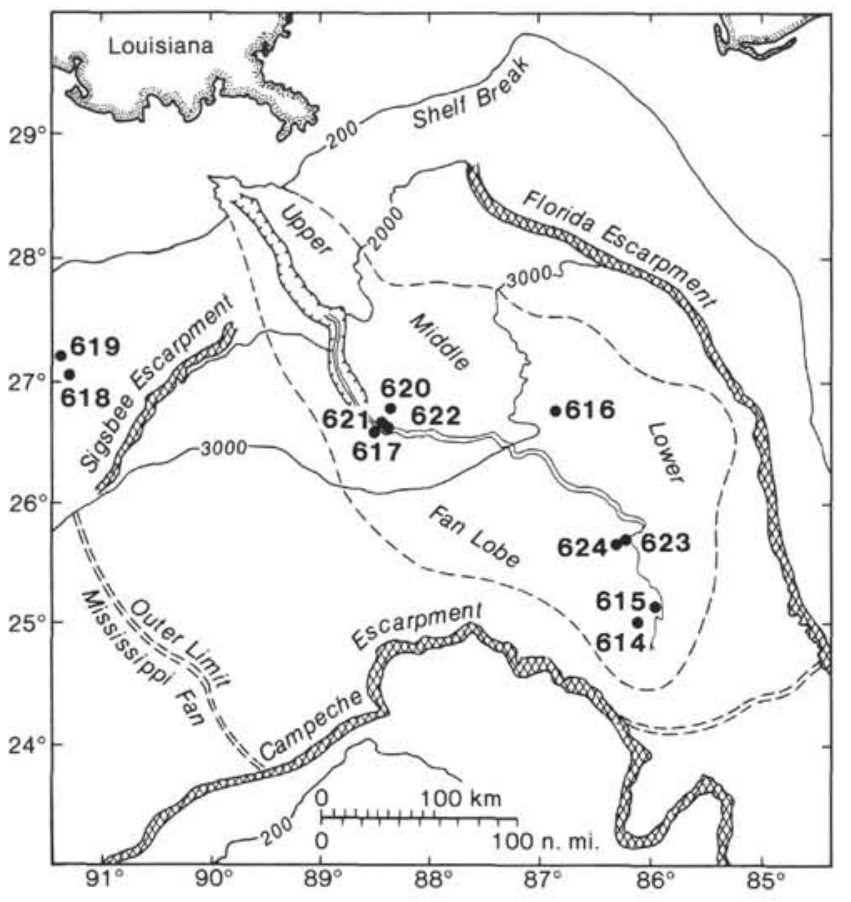

Figure 2. Schematic map of the youngest fan lobe of the Mississippi Fan (dashed outline) with the locations of the Leg 96 drill sites, including those of the intraslope basins.
Core recovery typically was high $(70-100 \%)$ in the upper 80 to $90 \mathrm{~m}$ of the sediment column at each site. Below that depth the recovery dropped sharply in an irregular manner. Sands thicker than 20 to $25 \mathrm{~cm}$ could seldom be retrieved without disturbance; they were either completely fluidized or could not be retained by the core catcher assembly and thus were not recovered at all.

Depth of coring varied considerably (Table 1). The majority of the proposed drill sites had been approved by the Joint Oceanographic Institutions Deep Earth Sampling (JOIDES) Pollution Prevention and Safety Panel to sub-bottom depths of only $200 \mathrm{~m}$, with three holes to a greater depth to penetrate the entire youngest fan lobe. At these deeper sites, the unconsolidated nature of the sediment caused excess friction on the drill collar which jeopardized our ability to retrieve the drill pipe. This meant that those holes could not be extended all the way to their proposed penetration depths. At Site 616, the lower drill collar became totally stuck and had to be severed. For safety reasons, organic geochemists on board ship continuously monitored recovered cores for the presence of gas; contrary to expectations, only small amounts or traces of gas were encountered.

Several wireline coring systems were used. The advanced hydraulic piston core (APC) and the extended core barrel $(\mathrm{XCB})$ were utilized most frequently, the latter one commonly at greater sub-bottom depths. Both types were exchanged several times in single holes in an attempt to collect better and longer cores. The rotary

Table 1. Drilling sites and general core information, Leg 96.

\begin{tabular}{|c|c|c|c|c|c|c|c|c|}
\hline Site & $\begin{array}{l}\text { Latitude } \\
\text { (N) }\end{array}$ & $\begin{array}{l}\text { Longitude } \\
\text { (W) }\end{array}$ & $\begin{array}{l}\text { Water } \\
\text { depth } \\
\text { (m) }\end{array}$ & $\begin{array}{l}\text { Penetration } \\
\text { depth } \\
\text { (m) }\end{array}$ & $\begin{array}{l}\text { Amount } \\
\text { cored } \\
(\mathrm{m})\end{array}$ & $\begin{array}{l}\text { Core } \\
\text { recovery } \\
(\%)\end{array}$ & $\begin{array}{c}\text { Type } \\
\text { of } \\
\text { cores }^{a}\end{array}$ & $\begin{array}{l}\text { Type of } \\
\text { well } \\
\log s^{b}\end{array}$ \\
\hline $614^{\mathrm{c}}$ & $20^{\circ} 04.08^{\prime}$ & $86^{\circ} 08.21^{\prime}$ & 3314 & 37.0 & 37.0 & 100 & $\mathrm{HPC} / \mathrm{XCB}$ & - \\
\hline $614 \mathrm{~A}$ & $25^{\circ} 04.08^{\prime}$ & $86^{\circ} 08.21^{\prime}$ & 3314 & 150.3 & 75.0 & 75 & $\mathrm{HPC} / \mathrm{XCB}$ & - \\
\hline 615 & $25^{\circ} 13.34^{\prime}$ & $85^{\circ} 59.53^{\prime}$ & 3284 & 523.2 & 419.3 & 42 & $\mathrm{HPC} / \mathrm{XCB}$ & $\begin{array}{l}\text { DIL, LSS, GR } \\
\text { FDC, CNL, GR }\end{array}$ \\
\hline $615 A^{d}$ & $25^{\circ} 13.35^{\prime}$ & $85^{\circ} 59.55^{\prime}$ & 3285 & 208.5 & 74.5 & 70 & $\mathrm{HPC} / \mathrm{XCB}$ & \\
\hline $616^{\mathrm{e}}$ & $26^{\circ} 48.67^{\prime}$ & $86^{\circ} 52.83^{\prime}$ & 2999 & 371.0 & 307.8 & 47 & $\mathrm{HPC} / \mathrm{XCB}$ & FDC, CNL, GR \\
\hline $616 \mathrm{~A}$ & $26^{\circ} 48.65^{\prime}$ & $86^{\circ} 52.86^{\prime}$ & 2999 & 132.4 & 38.4 & 63 & $\mathrm{HPC} / \mathrm{XCB}$ & \\
\hline $616 \mathrm{~B}^{\mathrm{d}}$ & $26^{\circ} 48.66^{\prime}$ & $86^{\circ} 52.85^{\prime}$ & 2999 & 204.3 & 143.2 & 79 & $\mathrm{HPC} / \mathrm{XCB}$ & \\
\hline 617 & $26^{\circ} 41.93^{\prime}$ & $88^{\circ} 31.67^{\prime}$ & 2478 & 191.2 & 130.1 & 86 & $\mathrm{HPC} / \mathrm{XCB}$ & \\
\hline $617 A^{d}$ & $26^{\circ} 41.93^{\prime}$ & $88^{\circ} 31.67^{\prime}$ & 2478 & 73.0 & 73.9 & 77 & $\mathrm{HPC} / \mathrm{XCB}$ & \\
\hline 618 & $27^{\circ} 00.68^{\prime}$ & $91^{\circ} 15.73^{\prime}$ & 2422 & 92.5 & 78.0 & 87 & $\mathrm{HPC} / \mathrm{XCB}$ & \\
\hline $618 A^{f}$ & $27^{\circ} 00.68^{\prime}$ & $91^{\circ} 15.73^{\prime}$ & 2422 & 47.6 & 28.7 & 65 & $\mathrm{HPC} / \mathrm{XCB}$ & \\
\hline 619 & $27^{\circ} 11.61^{\prime}$ & $91^{\circ} 24.54^{\prime}$ & 2274 & 208.7 & 134.4 & 83 & $\mathrm{HPC} / \mathrm{XCB}$ & \\
\hline $619 \mathrm{~A}^{\mathrm{g}}$ & $27^{\circ} 11.61^{\prime}$ & $91^{\circ} 24.54^{\prime}$ & 2273 & 5.3 & 5.3 & 100 & $\mathrm{HPC} / \mathrm{XCB}$ & \\
\hline 620 & $26^{\circ} 50.12^{\prime}$ & $88^{\circ} 22.25^{\prime}$ & 2612 & 422.7 & 421.3 & 47 & F93 CK & DIL, LSS, GR \\
\hline 621 & $26^{\circ} 43.86^{\prime}$ & $88^{\circ} 29.76^{\prime}$ & 2485 & 214.8 & 157.3 & 87 & $\mathrm{HPC} / \mathrm{XCB}$ & $\begin{array}{l}\text { LSS, GR, CAL, } \\
\text { FDC, CNL, GR }\end{array}$ \\
\hline 622 & $26^{\circ} 41.41^{\prime}$ & $88^{\circ} 28.82^{\prime}$ & 2495 & 208.0 & 132.7 & 75 & $\mathrm{HPC} / \mathrm{XCB}$ & LSS, GR, CAL \\
\hline $622 \mathrm{~A}^{\mathrm{g}}$ & $26^{\circ} 41.41^{\prime}$ & $88^{\circ} 28.82^{\prime}$ & 2495 & 5.6 & 5.6 & 99 & $\mathrm{HPC} / \mathrm{XCB}$ & \\
\hline 623 & $25^{\circ} 46.09^{\prime}$ & $86^{\circ} 13.84^{\prime}$ & 3188 & 202.2 & 110.2 & 81 & $\mathrm{HPC} / \mathrm{XCB}$ & LSS, GR, CAL \\
\hline 624 & $25^{\circ} 45.24^{\prime}$ & $86^{\circ} 16.63^{\prime}$ & 3198 & 199.9 & 109.8 & 69 & $\mathrm{HPC} / \mathrm{XCB}$ & \\
\hline $624 \mathrm{~A}^{\mathrm{d}}$ & $25^{\circ} 45.24^{\prime}$ & $86^{\circ} 16.63^{\prime}$ & 3198 & 207.6 & 103.7 & 84 & $\mathrm{HPC} / \mathrm{XCB}$ & $\begin{array}{l}\text { DILL, LSS, GR } \\
\text { FDC, CNL, GR }\end{array}$ \\
\hline
\end{tabular}

\footnotetext{
${ }^{\mathrm{a}} \mathrm{HPC}=$ hydraulic piston core, includes advanced piston core and variable length hydraulic piston core; $\mathrm{XCB}=\mathrm{eX}-$ tended core barrel system, usually used below 100 to $130 \mathrm{~m} ; \mathrm{F} 93 \mathrm{CK}=$ standard rotary coring bit.

${ }^{b}$ DIL = dual-induction lateral log, LSS = long-spaced sonic log, GR = gamma-ray log, FDC = formation density $\log , \mathrm{CNL}=$ compensated neutron $\log , \mathrm{CAL}=$ caliper log.

c Core barrel separated, round trip required.

d Extra continuous core for shore-based geotechnical studies.

e Pipe stuck, severing required.

${ }^{f}$ Extra cores for geochemical studies.

$\mathrm{g}$ Extra cores for paleontological studies.
} 
corer was used only at Site 620 because of the deep penetration proposed.

Initially, we planned to log only one deep hole on the middle fan and one on the lower fan. However, because of the generally poor core recovery at depths greater than 80-90 m sub-bottom, as many holes were logged as possible (Table 1; see Coleman, Bouma, et al., this volume).

\section{MAJOR DRILLING OBJECTIVES}

The drilling objectives for Leg 96 can be divided into two groups: those for the Mississippi Fan sites and those for the intraslope basin sites.

The main objectives for drilling on the fan were to:

1. Confirm or modify existing models of facies characteristics and distributions for modern fans in a passive margin setting, as these models are currently based only on acoustical properties and near-surface sediment characteristics.

2. Determine if the midfan channel with its sinuous pattern represents a lateral migratory and vertical aggradational system comparable to meandering fluvial systems.

3. Determine the lithologic nature of the acoustic highamplitude zone seen on reflection records near the bottom of the channel fill.

4. Determine if the fill of the midfan channel is active and/or passive and if it is a fining-upward sequence.

5. Determine if the mode of frequent channel switching suggested for the upper part of the lower fan can be supported by the findings of the drill.

6. Determine whether the deposits near the termini of the lower fan channels are sandy, comparable with ancient turbidite system depositional lobes, with coarsening and thickening upward cycles.

7. Determine if the overbank deposits are characterized by thin-bedded turbidites or by primarily muddy deposits.

8. Analyze the role of mass movement deposits in the fan subenvironments.

9. Establish the lithologic nature of prominent seismic reflectors in the sedimentary column.

10. Determine the stratigraphic framework of the modern fan lobe, of underlying fan lobes, and of the prominent acoustic reflectors.

11. Study the possible relationship between constructional phases of fan lobe deposition and sea-level variations.

12. Characterize the sedimentary and geotechnical properties of the sediments from different subenvironments.

13. Establish the source(s) of the different fan sediments.

14. Analyze the organic and inorganic geochemical characteristics of the sediments and the effects of initial diagenesis.

15. Construct a predictive model for this type of a submarine fan using seismic, core, and laboratory data.

The main drilling objectives for the intraslope basins were to:

1. Establish the age of the sediments in the upper $200 \mathrm{~m}$ of the sediment column.
2. Obtain a high-resolution fossil record of the late Neogene and correlate that with oxygen-isotope data and with magnetic stratigraphy.

3. Establish the time of introduction of the brine in Orca Basin.

4. Establish the influence of the brine on the deposition of fine-grained sediments and compare those anoxic sediments with the underlying oxic deposits.

5. Establish the sediment types in Pigmy Basin in relation to the seismic facies and relate the findings to sealevel variations.

6. Attempt to relate stratigraphic data to diapiric activity.

7. Determine the physical and geotechnical characteristics of the sediments deposited under different conditions in these intraslope basins.

\section{INTERNAL STRUCTURE OF THE MISSISSIPPI FAN}

Eight major seismic reflectors can be correlated regionally across the Mississippi Fan. These correlations permit the construction of a regional dip profile which shows thickening and thinning of the sediment slices between reflectors, hereafter called fan lobes. A fan lobe is defined as a body of submarine fan deposits that accumulated during a relatively short geological interval and is separated from underlying and adjacent fan lobes by seismic reflectors that can be correlated across the extent of that fan lobe ${ }^{3}$. Sufficient seismic coverage is available to construct structural contour (paleo-isobaths) and isopach maps of these fan lobes.

The reflector horizons are numbered for easy reference. Their numbers and tentative ages are as follows:

Horizon " 0 "- present seafloor

Horizon "10"-middle late Wisconsin, difficult to trace regionally

Horizon " 20 "- late Wisconsin-40,000-55,000 yr. ago

Horizon "30"-early Wisconsin-75,000-100,000 yr. ago

Horizon " 40 " - middle Pleistocene

Horizon " 50 "- middle Pleistocene-about 500,000 yr. ago (Trimosina A Zone)

Horizon "60"-middle Pleistocene (Hyalinea balthica Zone?)

Horizon "70"-base of Pleistocene-1.6 m.y. ago (Lenticulina 1 Zone)

Horizon "80"-Pliocene (?) (Lenticulina 1 Zone)

The ages of these reflector horizons were based on drill holes and soil foundation borings along the rim of the present Mississippi Canyon at the edge of the shelf and the upper continental slope. Reflector horizons from the Mississippi Canyon area were traced seaward toward the seismic grid that covers the Mississippi Fan. The age assignments are considered tentative, as seismic correlations could not be made along several of the seismic lines because of the presence of diapirs on the continental slope and at the Sigsbee Escarpment. Instead, corre-

\footnotetext{
${ }^{3}$ The Leg 96 shipboard scientific party prefers to consider the term "fanlobe" a single word. This term, however, appears throughout this volume as two separate words as a matter of editorial policy.
} 
lations were made around those structures using other available seismic lines which often necessitated projecting reflectors across small diapiric spines. Each reflector horizon was digitized and corrected for velocity using a downhole velocity survey acquired from one of the industrial drill holes along the margin of the Mississippi Canyon (Fig. 3). These processed data provided depth in meters to each reflector horizon at each shot point; from these data, contour and isopach maps were constructed (Fig. 4).

The datum of these isopach and structure contour maps is present sea level. Because of the lack of sufficient penetration on many of the seismic records, these maps become more incomplete and generalized with depth. The paleosurface of Horizon 80 shows some relief, and in the vicinity of the upper fan, it is in excess of $6 \mathrm{~km}$ from our datum. The water depth in the upper fan area is approximately $2.5 \mathrm{~km}$, resulting in a thickness of about $3.5 \mathrm{~km}$ of late Pliocene and Pleistocene fan deposits. It is likely that this thickness increases toward the base of the present continental slope.

Each structure and isopach map shows sufficient complexity to indicate that each mapped interval represents more than a single fan lobe. However, refinement cannot be accomplished until a denser grid of seismic coverage becomes available. In spite of these complexities, a number of general deductions can be made by comparing the individual maps. It appears that fan lobes tend to overlap and that the maximum thickness of each one is located in a topographic low between older underlying and adjacent fan lobes. In addition, there is a general migration from west to east, as well as toward deeper water when comparing maps of older fan lobes with those of younger ones. Because each fan lobe is

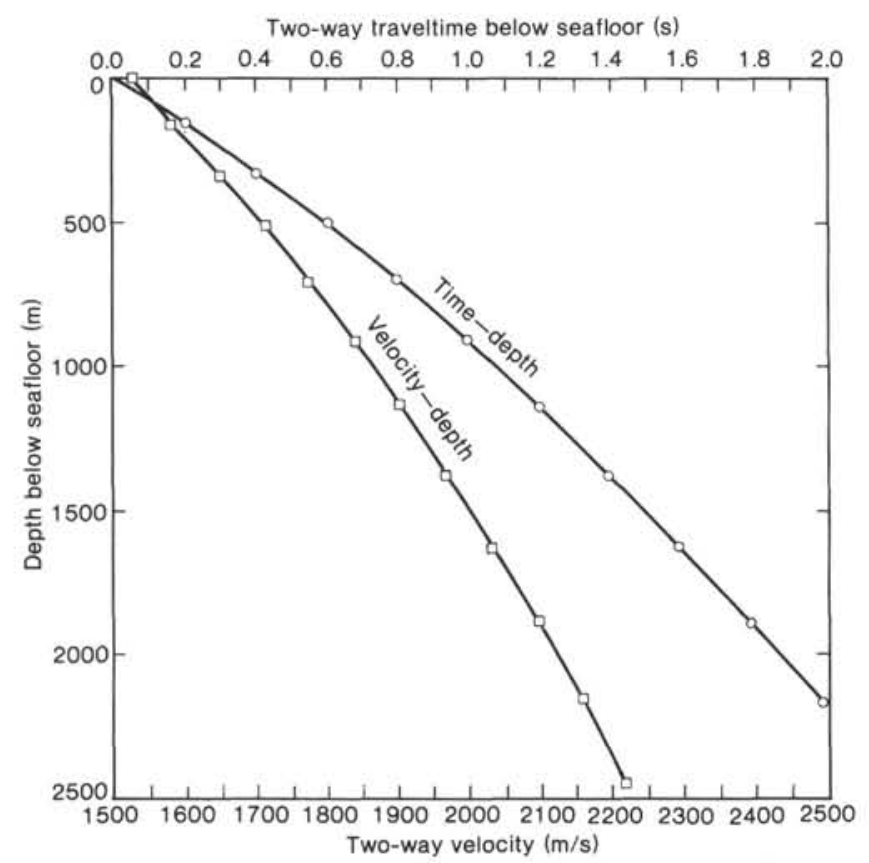

Figure 3. Plot of velocity and time versus depth. The basic data used to produce this graph are from borings around the Mississippi Canyon. (See Explanatory Notes, this volume.) connected to a submarine canyon that supplied the sediments, these canyons also shifted eastward through time; complexity of the diapirs on the continental slope of Louisiana prohibits us from connecting each fan lobe to a specific submarine canyon. However, a number of canyons do exist along the shelf break and along former shelf breaks, although they have been completely filled in and do not appear as topographic depressions on the seafloor.

The youngest fan lobe (Fig. 4, Horizon "0"-“20") clearly illustrates the influence of underlying topography in controlling fan lobe position and location. The modern channel is located over the maximum isopach thicknesses and occupies the present bathymetric high. Also, the bend in the channel at $26^{\circ} 30^{\prime} \mathrm{N}$ latitude corresponds to the zone of thicker underlying fan lobes.

\section{YOUNGEST FAN LOBE}

The fan lobes between Horizons " 0 " and " 20 " are grouped together as the youngest fan lobe because of the impossibility of correlating Horizon " 10 " or any other horizon younger than Horizon " 20 " across the entire fan. Utilizing the large volume of available seismic reflection data, consisting of high- and medium-resolution types, as well as multichannel CDP records, together with GLORIA side-scan data (Garrison et al., 1982), a seismic facies model was constructed for the Mississippi Fan. This schematic model of the youngest fan lobe illustrates changes in the overall shape and acoustical nature of cross sections in a basinward direction. The older fan lobes likely have similar features.

In a strike direction the fan lobe is more or less lenticular in shape with its thickest part centrally located. In a dip direction the lens is asymmetrical with the thickest section being located on the landward end of the center with a minor thinning toward its source and considerable thinning basinward.

Figure 5 presents a schematic plan of the fan lobe model. This elongated fan lobe can be divided into four major regions, each having its own morphologic and seismic characteristics schematically displayed in Figure 6:

1. An upslope erosional canyon, incised into the shelf and upper slope (Fig. 6A),

2. An upper fan region with a large, nearly filled, erosional channel which acted as a conduit during fan accumulation and became filled once that activity ceased (Fig. 6B),

3. An aggradational middle fan region, more or less lenticular in cross section, with a sinuous channel near its center (Fig. 6C), and

4. An aggradational lower fan region with a system of multiple small channels that have "sheet sand" deposition at their basinward terminations (Figs. 6D and E).

\section{Upslope Erosional Canyon: Mississippi Canyon}

The Mississippi Canyon or Trough was originally interpreted as the result of massive submarine slumping events, the positions of which were controlled largely by near-surface active diapirs (Shepard, 1937; Gealy, 1955). Subaerial erosion and cutting of the canyon by sandladen density flows was preferred by Bates (1953), Fisk 

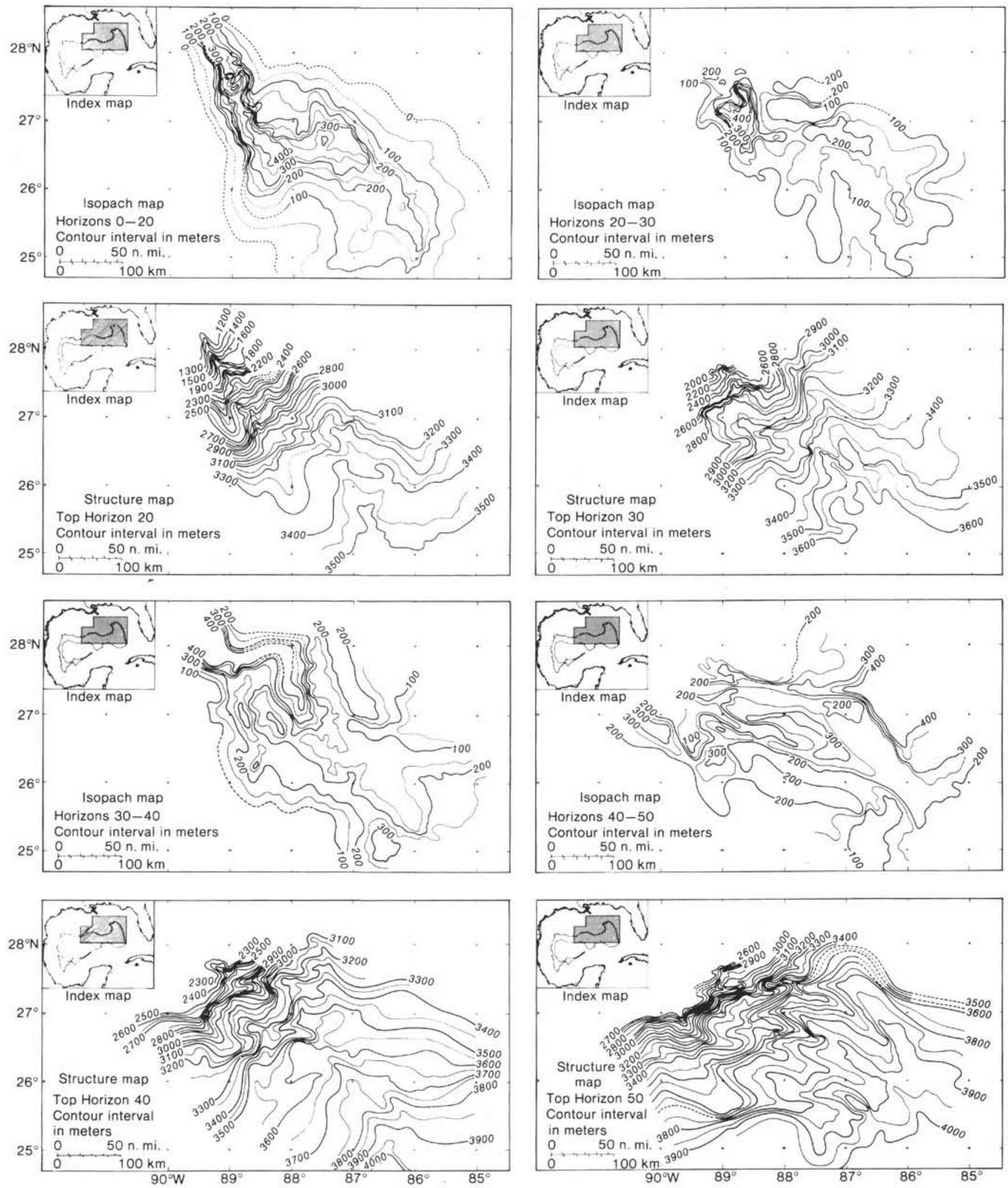

Figure 4. Isopach and structure maps of selected fan lobes of the Mississippi Fan. (After Bouma, Stelting, et al., 1985.) 


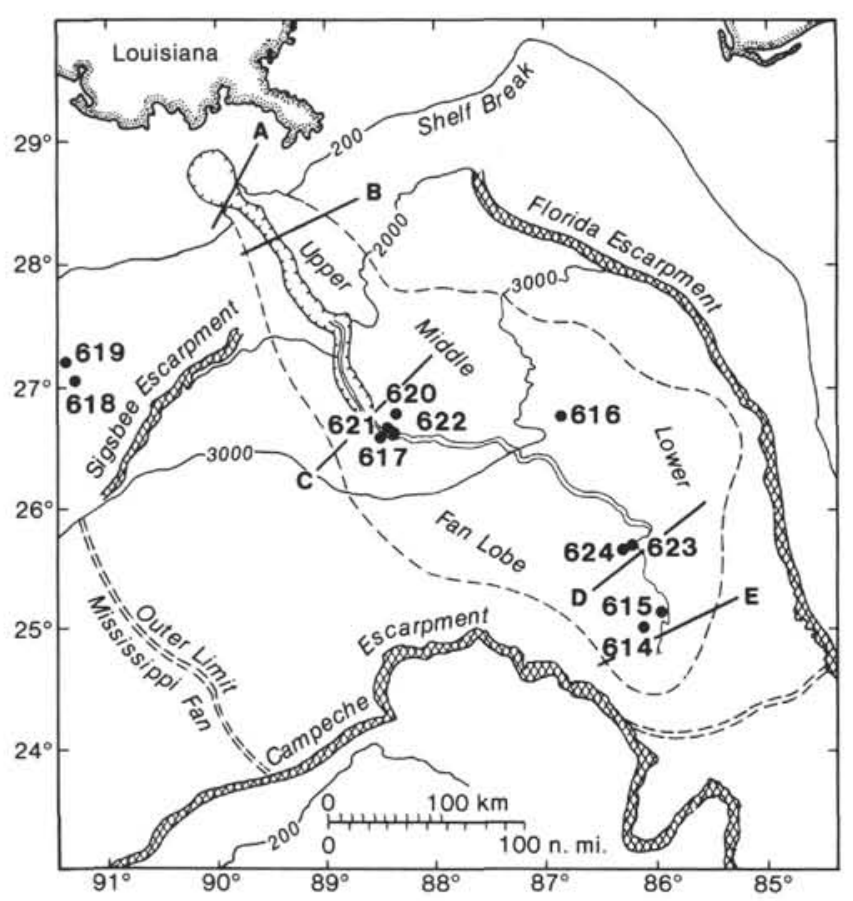

Figure 5. Schematic plan of the youngest fan lobe with locations of cross sections presented in Figure 6. (After Bouma, Coleman, et al., 1985.)

and McFarlan (1955), and Phleger (1955). Many seismic records and much engineering core-hole data from the canyon area were summarized by Ferebee and Bryant (1979), adding considerable knowledge to the geometry and characteristics of the canyon fill. Coleman et al. (1983) used a dense seismic grid and deep-borehole information through the entire canyon fill and through the adjacent undisturbed deposits to conclude that the canyon had formed in a relative short time by massive failures of shelf-edge and upper-slope sediments.

The present bathymetry of the Mississippi Canyon starts in a water depth of about $80 \mathrm{~m}$ and continues for a distance of approximately $180 \mathrm{~km}$, where it becomes the upper Mississippi Fan at a water depth of about $1200-1500 \mathrm{~m}$. The overall channel width ranges from less than $5 \mathrm{~km}$ to greater than $15 \mathrm{~km}$. The channel gradient rarely exceeds $1: 125$, whereas the adjacent continental slope has a gradient of $1: 30$ to $1: 90$. Figure $7 \mathrm{~A}$ shows a 12-channel seismic profile across the canyon. The labeled reflector horizons were dated by radiocarbon and paleontological determinations (Coleman et al., 1983). Their ages are as follows:

Horizon A-present seafloor

Horizon B-base of Holocene (10,000-12,000 yr. ago)

Horizon C-late Wisconsin ( 15,000 yr. ago)

Horizon D-slump fill (older material from side walls) Horizon E-base of canyon (22,000-25,000 yr. ago)

Horizon F-late Wisconsin (25,000-27,000 yr. ago)

Horizon G-late middle Wisconsin (50,000 yr. ago)

Horizon $\mathrm{H}-$ early Wisconsin $(60,000-75,000$ yr. ago $)$

Horizon I-base of Illinoian Glacial Stage $(350,000-$ 400,000 yr. ago)
A

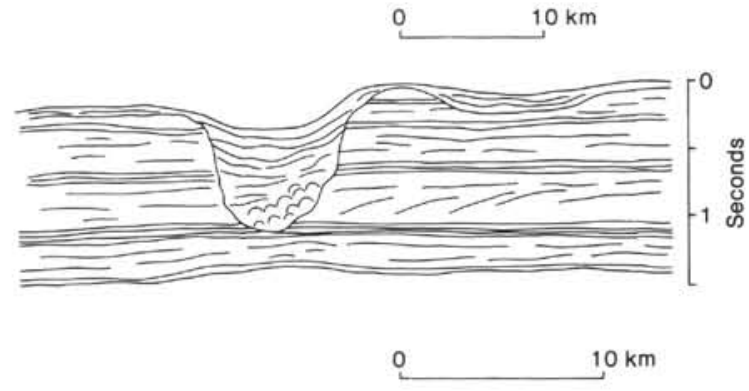

B

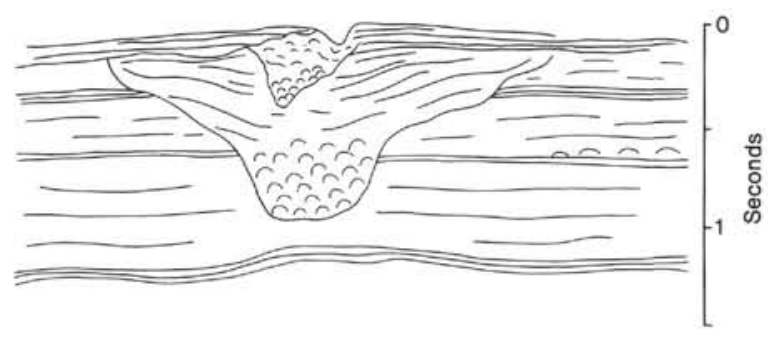

C

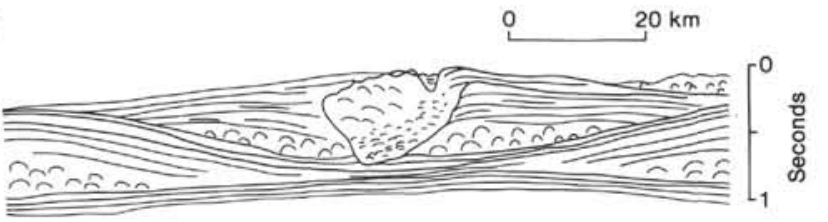

D

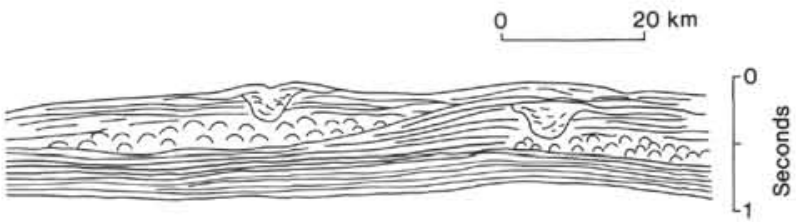

E

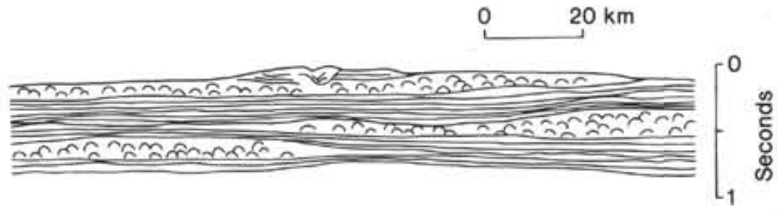

Figure 6. Generalized drawings of seismic reflection profiles from different areas of the youngest fan lobe presenting the main acoustical facies characteristics. (After Bouma, Coleman, et al., 1985.)

These acoustical horizons display good lateral continuity and can be used to construct structural and isopach maps depicting the evolution of the canyon (Fig. 7B). The seismic data show that the canyon formed postHorizon F (25,000-27,000 yr. ago) because this horizon, as well as Horizons $\mathrm{G}$ and $\mathrm{H}$, was cut by the base of the canyon. Infilling of the canyon started about $20,000 \mathrm{yr}$. ago and was virtually completed by 10,000 yr. ago. Any mechanism proposed for the origin of the canyon must account for the evidence that this large feature formed over an interval of about 7000 yr. or less.

Structural contours of Horizon $\mathrm{H}$ show the cutting of this horizon as the canyon was formed. A trend surface computer program was used to reconstruct the sur- 
A

$\begin{array}{ll}\text { A } & A^{\prime}-0\end{array}$

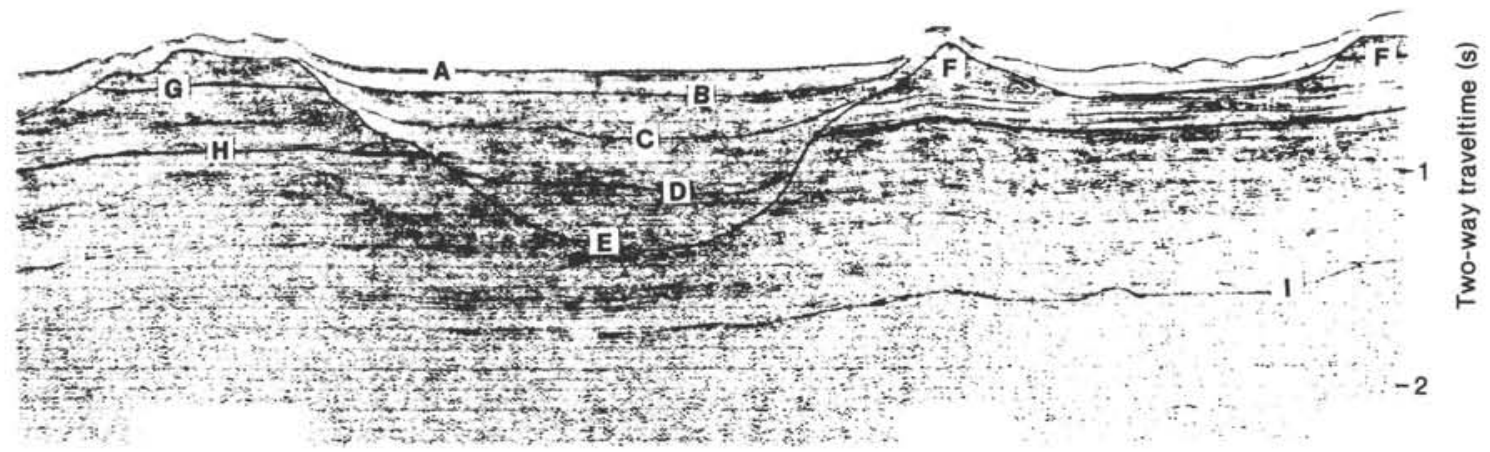

B

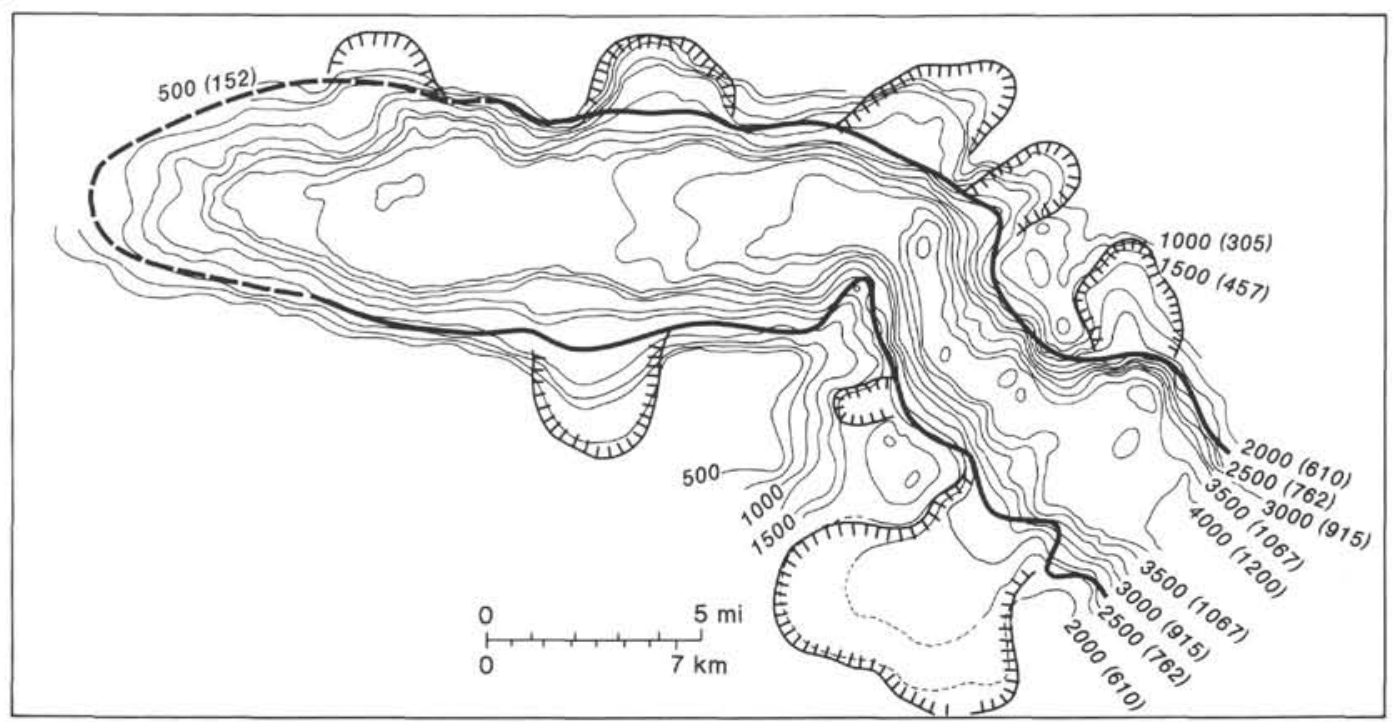

Figure 7. A. Seismic profile (12-channel) across the Mississippi Canyon. B. Structure map of Horizon E. Slope $0.3-0.5^{\circ}$, contour interval $250 \mathrm{ft}$. (76 m). (After Coleman, et al., 1983.)

face as it existed prior to the canyon cutting. This surface has a $1.5^{\circ}$ seaward slope, and the canyon axis is about at right angles to the slope of the surface. A structural contour map of Horizon E, the base of the erosional surface of the canyon (Fig. 7B), shows that the head of the canyon had cut to about $150 \mathrm{~m}$ below sea level and in the southeastern part of the canyon to about $1220 \mathrm{~m}$ below sea level (Coleman et al., 1983). The gradient along the base of the canyon axis is about 0.3 to $0.5^{\circ}$, which is much lower than that of the reconstructed horizons through which the canyon was excavated. While the canyon floor was rather flat, side walls were fairly steep, with slopes approaching 23 to $25^{\circ}$. These sidewall slopes formed by slumping along the wall as the canyon sides attempted to regain stability; slump scars can be seen in Figure 7B. An isopach map from the base of the canyon (Horizon E) to the top of the slump fill (Horizon D) shows thickened masses of sediment opposite the major slump scars on the canyon wall sides.

The Mississippi Canyon fill is approximately $600 \mathrm{~m}$ thick; the infilling is not completed. This fill consists primarily of clay containing a reworked shallow-water fauna.

\section{Upper Fan}

The boundary between the canyon and the upper fan regions is gradual, the latter being distinguished from the canyon by a broad, nearly filled, erosional channel with wide, low levees and a small, slightly irregular channel cut into the center of the fill (Fig. 6B).

The lower boundary of the upper fan is located near the base of the continental slope in water depths ranging from 2100 to $2300 \mathrm{~m}$. The erosional channel on the upper fan widens significantly in a downfan direction. An increase of aggradation also gradually becomes apparent with seismic reflectors offlapping onto the adjacent continental slope, interpreted as representing "overbank deposits." Figure 6B schematically illustrates the most common seismic facies types in this region of the fan. The lower part of the channel is erosional in nature, and the lower channel fill shows chaotic reflectors, similar to those observed in the canyon fill. However, the chaotic 
fill is thicker on the upper fan and it often interfingers with parallel acoustic reflectors. Above the lower fill, a well-developed sequence of conformable parallel onlapping reflectors forms the bulk of the middle section. The partial fill of the smaller erosional channel shows the same acoustical patterns.

\section{Middle Fan}

Near the base of the continental slope, the strong erosional character of the channel changes into an aggradational one. The total width and total thickness of the fan lobe continue to increase and reach their maximum values 40 to $60 \mathrm{~km}$ further downfan. These maximum dimensions for the youngest fan lobe are nearly $150 \mathrm{~km}$ and approximately $400 \mathrm{~m}$ for its width and thickness, respectively. The width to thickness ratio is $375: 1$.

The middle fan is lenticular in cross section (Fig. 6C) with a sinuous channel being located at its apex (Garrison et al., 1983; Bouma, Coleman, and Meyer, 1984; Kastens and Shor, 1985; Bouma, Stelting, and Coleman, 1985; Stelting, Pickering, et al., 1985).

A dense grid of parallel-oriented water gun seismic records, together with a nearly complete coverage of 5$\mathrm{km}$ and $1-\mathrm{km}$ swath Sea MARC side-scan sonar images, were collected during the Lamont-Doherty site survey cruise over a part of the middle fan channel where a distinct "meander belt" is present (Kastens and Shor, 1985).
Figure 8 presents a $5-\mathrm{km}$ swath record of part of the channel which shows as a nearly transparent image, except for some channel-parallel lineations. The image clearly indicates the "point bar" area with a convex line system which represents "ridges and swales." Very highresolution reflection profiles indicate reflectors that start at the levees and dip down toward the channel axis. The upper part of the channel fill is acoustically transparent on those records (see O'Connell et al., this volume). A sonograph record detail of ridges and swales (pressure ridges according to Kastens and Shor, 1985), located to the northwest of the previous sonograph (Fig. 8), is presented in Figure 9. Lack of high-resolution seismic data prohibits us from making a better interpretation of these phenomena.

The processed site survey side-scan sonar images were interpreted and the data plotted on the navigation chart. The results are presented in Figure 10. The sinuousity of the channel and other morphological characteristics, such as ridges and swales, revealed by side-scan sonar (Fig. 8), suggest a migratory nature of the midfan channel. The drilling results indicated that the presence of an acoustical high-amplitude zone at the base of the channel fill represents a "coarse-grained" lag deposit (Stelting et al., 1985 ) (see next section). The positions of the underlying fan lobes are reason for the change in direction of the upper fan channel as it passes onto the middle fan.

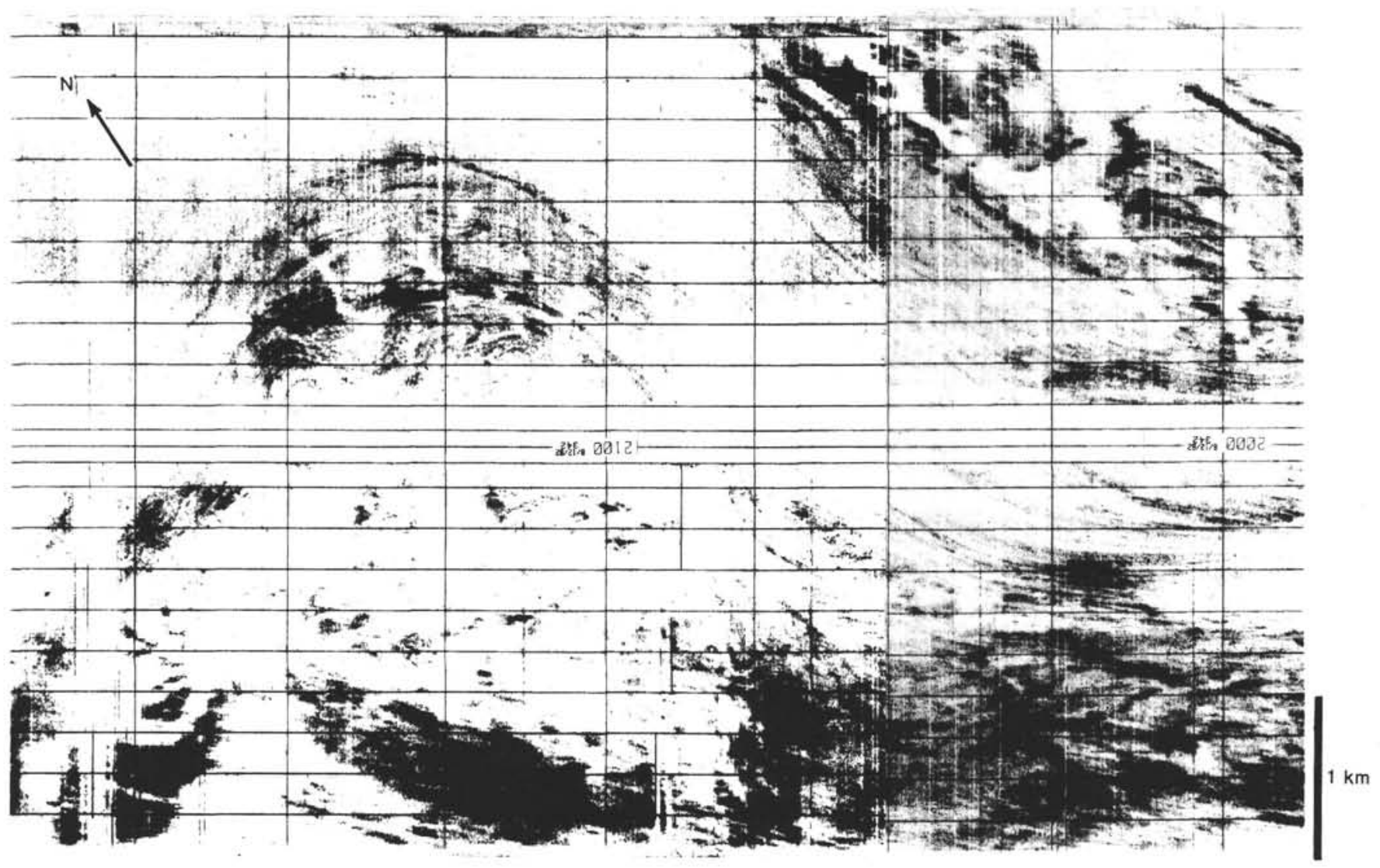

Figure 8. Sea MARC side-scan sonar image of part of the midfan channel meander belt (transparent zone) with ridge and swale structures on the "point bar" side (lower left half) as well as adjacent to the channel (upper right side of image). Vague channel lineations, parallel to the channel, can be observed on the channel floor between 2000 and $2100 \mathrm{hr}$. Width of total record is $5 \mathrm{~km}$ (2.7 n. mi.). (See also Kastens and Shor, 1985.) 


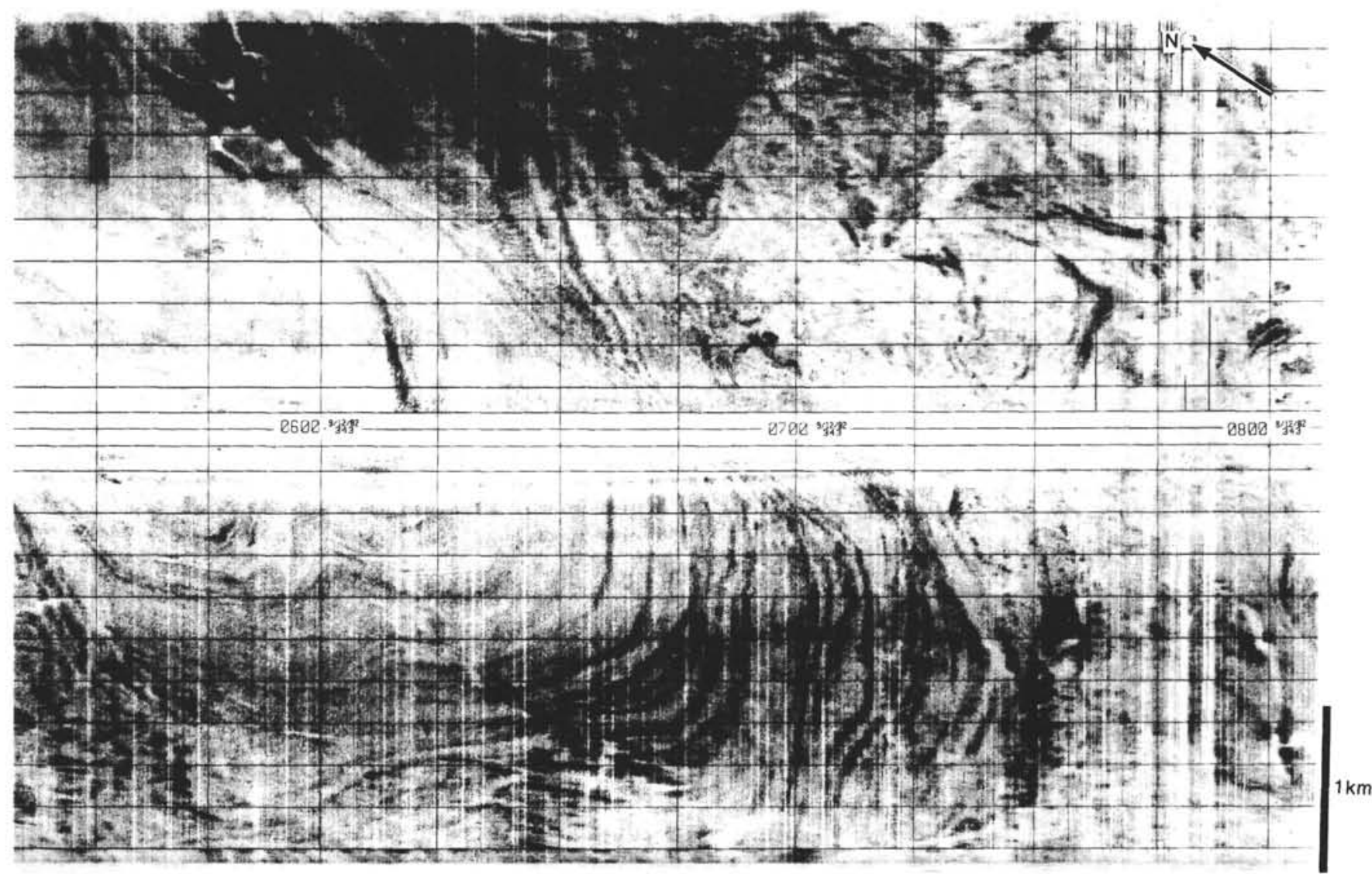

Figure 9. Sea MARC side-scan sonar image of ridge and swale topography about 12-km west of Figure 8. Kastens and Shor (1985, fig. 6) explain these features to be transverse pressure ridges in the main channel. Width of total record is $5 \mathrm{~km}(2.7 \mathrm{n}$. mi.).

The common seismic facies (Fig. 6C) includes the acoustical high-amplitude zone near the base of the channel described above. This high-amplitude zone can be followed deeper into the section, where it also widens in one direction indicating that the channel migrated laterally while aggrading vertically (Stelting and Leg 96 Shipboard Scientists, 1985). The acoustical character higher up in the channel fill is predominately semitransparent. Adjacent to the channel the reflectors become more parallel and offlapping, with onlap to the base of the fan lobe.

The width of the entire midfan channel complex is commonly 10 to $20 \mathrm{~km}$, whereas the central channel is normally only 2 to $4 \mathrm{~km}$ wide. Distinct levees bound the channel; the sequence of offlapping overbank reflectors that become more comformable near the lateral edges of the fan lobe is prominent.

Downfan, the width of the fan lobe remains approximately the same but its thickness decreases, giving a width to thickness ratio of 650:1. The central channel becomes smaller and less sinuous. Offlapping reflectors of the overbank deposits are still present and form the bulk of the fan lobe (Fig. 6C).

\section{Lower Fan}

At water depths of approximately 3100 to $3200 \mathrm{~m}$, both the surface area morphology and the characteristics of the seismic reflectors of the fan lobe change. The channel, as imaged on side-scan sonar (Fig. 11), often shows a double image giving the impression of a "midchannel island." The dimension and sinuosity of the channel have decreased considerably compared to the middle fan. Faint impressions on the sonographs, especially on original records from the upper part of the lower fan, indicate several more or less parallel images that are interpreted as abandoned channels (Fig. 11, upper right hand corner). Drilling, discussed in the next section, supports the most plausible interpretation that channel shifting occurred frequently on the lower fan and that only one channel was active at any given time ( $\mathrm{O}^{\prime}$ Connell et al., 1985). The processed side-scan sonar data were transferred to a map allowing interpretation of the surface characteristics of a large part of the lower fan (Fig. 12). The acoustical high-amplitude zone at the base of the channel fill becomes less prominent and thinner and gradually disappears downfan. The reflectors become more and more parallel and laterally continuous (Figs. 6D, E).

The thickness of the fan lobe decreases significantly and rarely exceeds $150 \mathrm{~m}$ at the downfan side. The width, as far as it is known, stays about the same, likely resulting from constraint by the Florida Escarpment on the east, the Campeche Escarpment on the west, and the Florida Straits to the south. The overbank and distal fan sequences become thin and, in many instances, it is difficult to separate one depositional unit from another.

Surface morphologic characteristics of the lower fan are not very supportive in characterizing subsurface features. The most recent channel and its adjacent aban- 


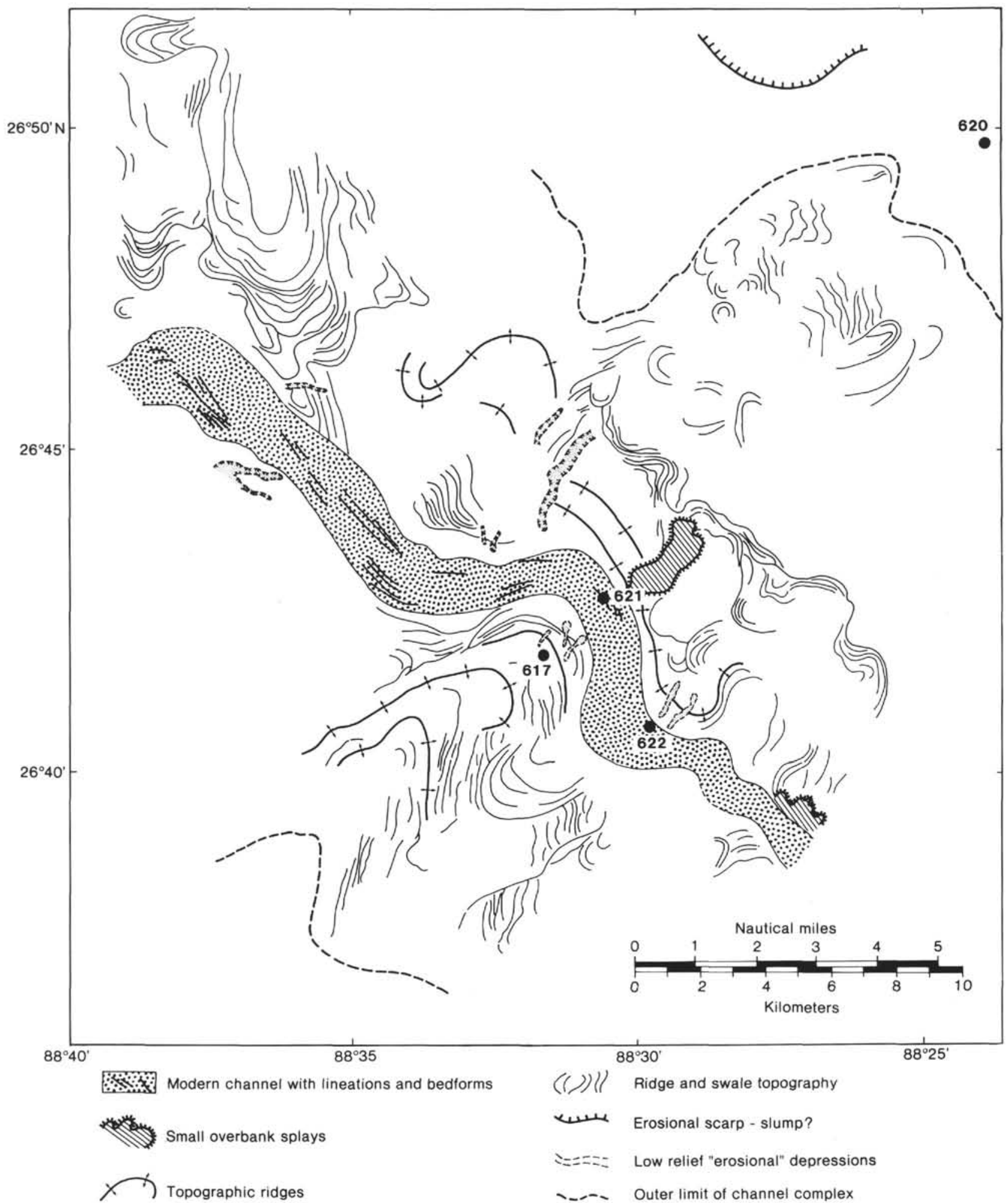

Figure 10. Morphology of part of the middle fan in the area of Sites 617, 620, 621, and 622. (Site 620 is actually farther to the right then shown). Data from GLORIA and Sea MARC side-scan sonar surveys. (After Stelting, Pickering, et al., 1985.)

doned ones may show bifurcation before they become unrecognizable on both side-scan sonar and very-highresolution seismic profiles (Fig. 12). The seismic reflectors become rather regular and parallel, thin and close together, and often somewhat discontinuous. Pre-coring interpretations suggested that these reflectors represent sand-sheet deposition based on the depositional lobes reported from ancient turbidite sequences (e.g., Mutti and Ricci Lucchi, 1972). The low core recovery of sandy sections and the fluidization of recovered sands (Table 1) 


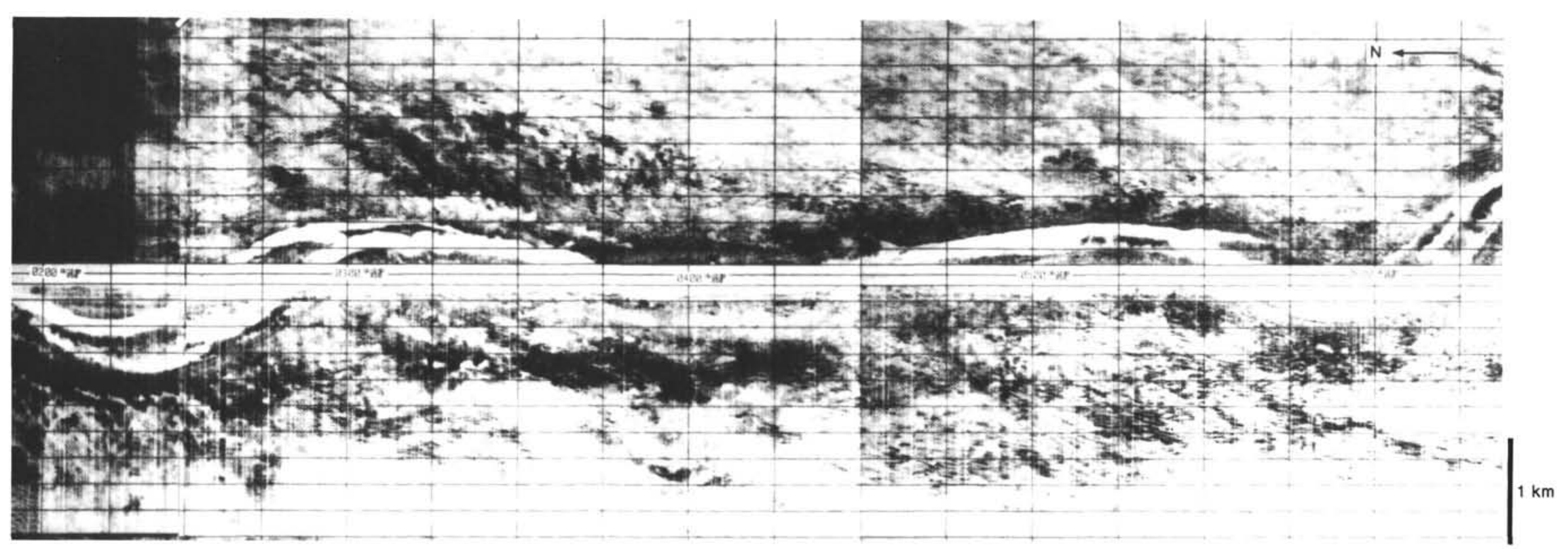

Figure 11. Sea MARC side-scan sonar image of portion of the lower fan showing a slightly sinuous channel, the dark area in the channel ("midchannel islands"), and some light channelized imprints (e.g., near 0300-0345 and 0510-0610) that are interpreted as older channel courses. Width of the total record is $5 \mathrm{~km}(2.7 \mathrm{n}$. mi.). 


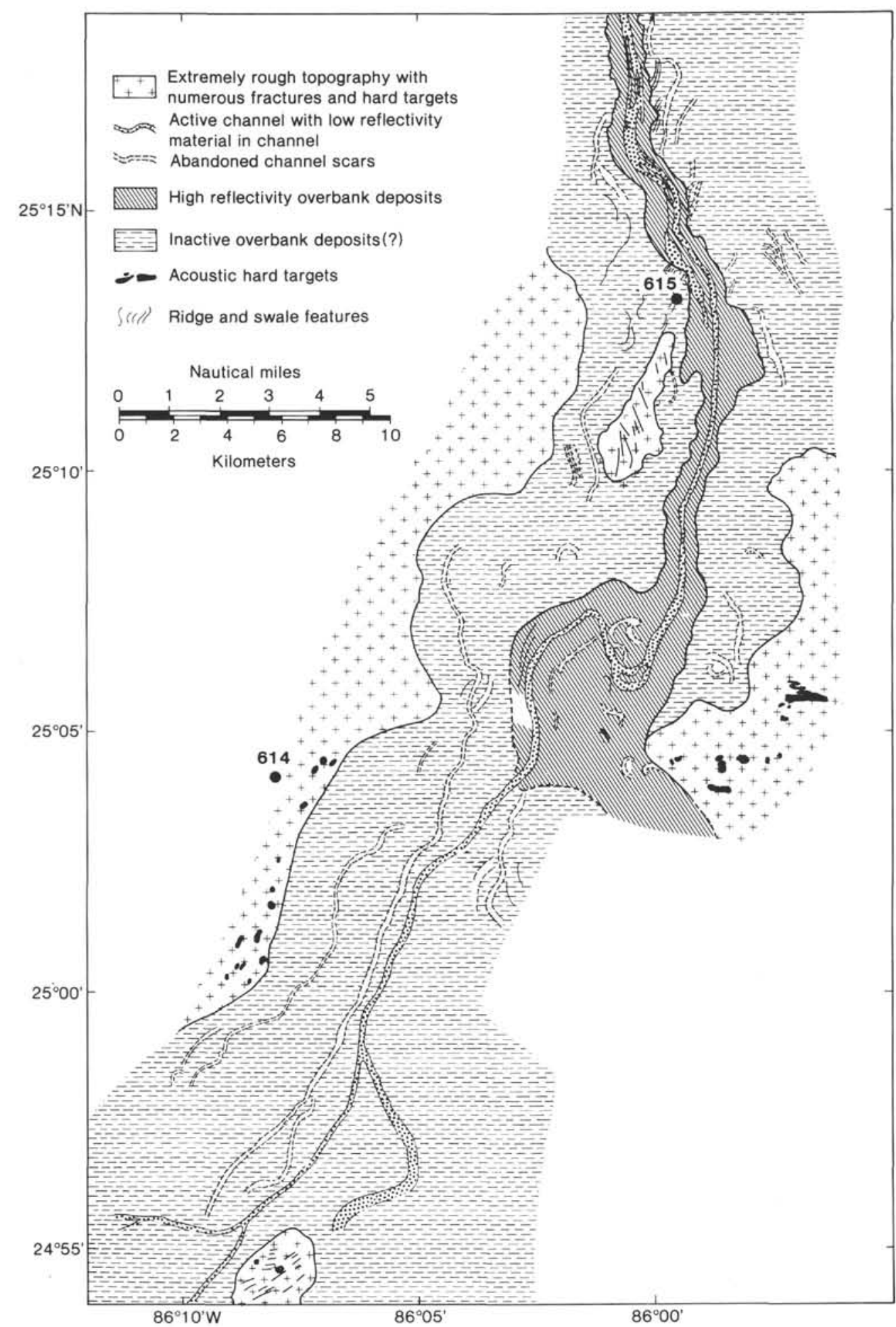

Figure 12. Morphology of the distal part of the lower fan with the locations of Sites 614 and 615 . Data based on Sea MARC side-scan sonar. (After O'Connell et al., 1985.)

prevent us from making detailed comparisons with studies of ancient turbidite systems (Normark et al., this volume).

This overall morphologic and seismic facies model for the youngest fan lobe of the Mississippi Fan could only be verified by continuous coring. Seismic analyses, however, strongly support the idea that the older, underly- ing fan lobes have the same lithologic characteristics and were constructed in a similar manner.

\section{GENERAL DRILLING RESULTS}

General information on core recovery, type of coring device used, and type of well logs collected at each site can be found in Table 1. By combining the core descrip- 
tions presented in the site chapters (this volume) with the well log data, a general lithologic column for each site was compiled (Figs. 13-21). Each figure contains stratigraphic zonations based on Ericson and Wollin (1968), depth below sea level and sub-bottom in meters and feet, major lithologies, and uncorrected well-log trace(s).

Figure 13 and 14 present the two midfan channel sites: Site 621 in the channel "thalweg" and Site 622 in the "point bar." Both sites bottomed at about $200 \mathrm{~m}$ in gravel overlain by sand and a pebbly mud. The depth coincides with the top of the acoustic high-amplitude zone, mentioned earlier (see Stelting et al., 1985). The nearest source of gravel is on the shelf near the head of the Mississippi Canyon (see Thayer et al., this volume). Both sites show a general fining upward from gravel to sand to interbedded sand, silt and mud, to more or less homogeneous mud. The lower sand section at the "point bar" site is about $30 \mathrm{~m}$ thicker than at the "thalweg" site, which is similar to fluvial systems. Such a finding

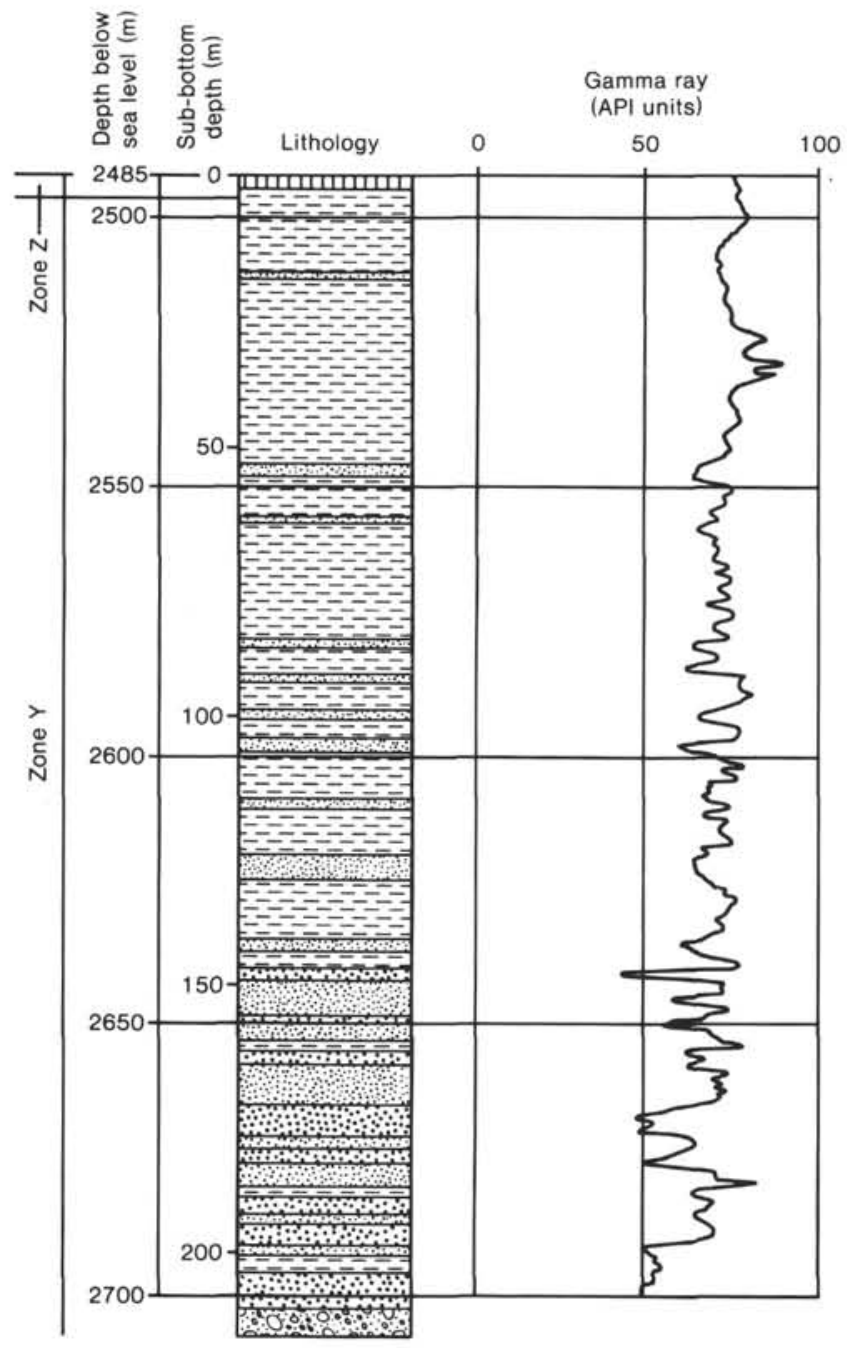

Figure 13. Site 621, middle fan channel: "thalweg site." Generalized lithologic column, stratigraphic zonation, uncorrected gamma-ray trace, and depth $(\mathrm{m})$ below sea level and sub-bottom. For legend see Figure 15. (Modified after Bouma, Coleman, et al., 1984.)

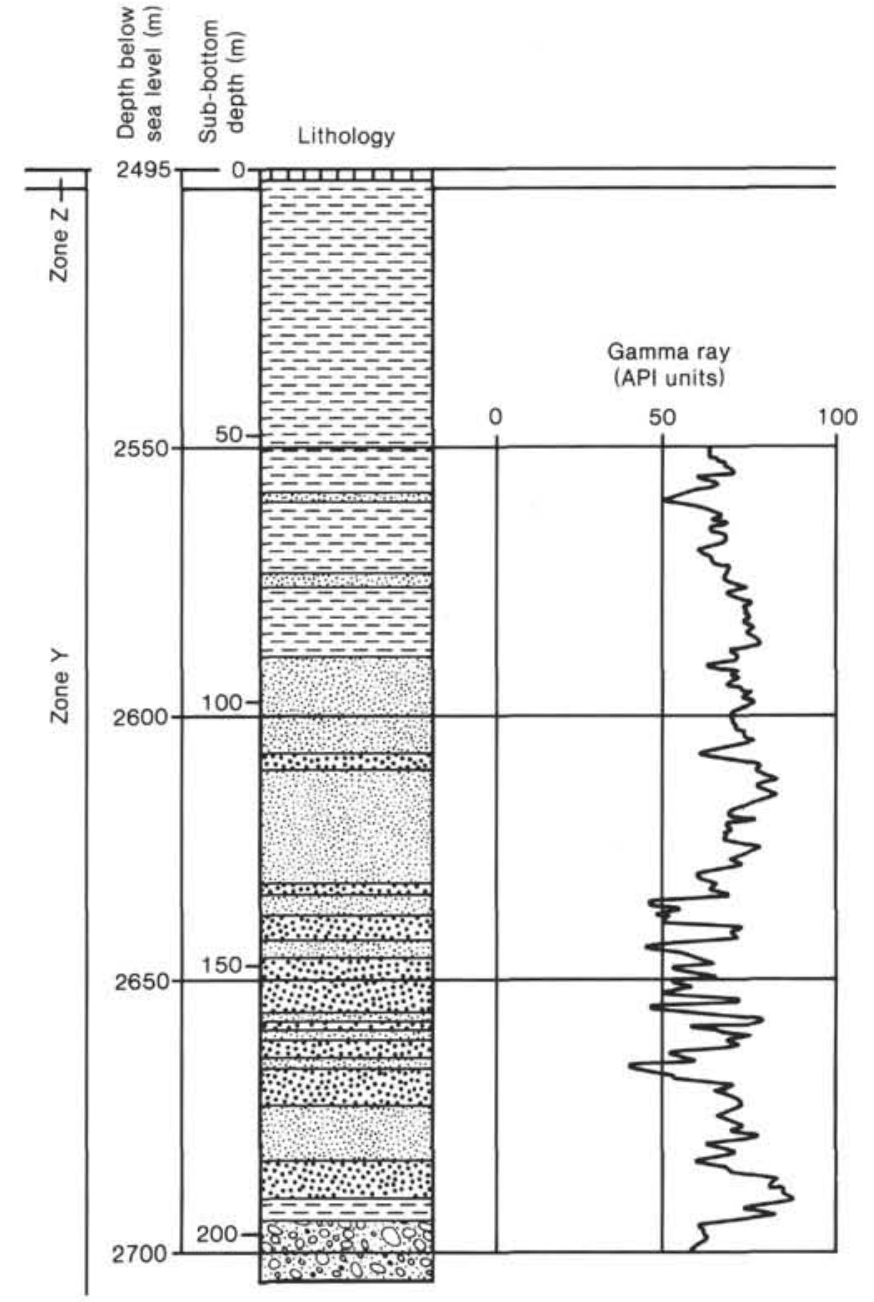

Figure 14. Site 622, middle fan channel: "point bar site." Generalized lithologic column, stratigraphic zonation, uncorrected gamma-ray trace, and depth $(\mathrm{m})$ below sea level and sub-bottom. For legend see Figure 15. (Modified after Bouma, Coleman, et al., 1984.)

adds support to our interpretation of a migratory midfan channel. Details of processed well-log shapes are given by Coleman, Constans, et al. (this volume); the unprocessed traces will therefore not be discussed further here.

At Site 617 , we drilled in a swale adjacent to the inner bend of the channel, showing a fine-grained section representing near-channel overbank deposits. No general vertical trends in lithologic characteristics exist. Thin bedding is common, representing fine-grained turbidites. Small-scale distortions are frequently observed and most of those are considered to represent local mass movements rather than coring distortions. Abundant smallscale cross-laminations indicate that bottom transport was active. No well logs were collected at this site (Fig. $15)$.

Site 620 was located farther away from the channel and recovered overbank deposits (Fig. 16). Lithologically, these sediments do not differ much from those of Site 617. However, the lithologic descriptions of the recovered cores have to be viewed with caution because of the relative greater degree of core disturbance caused by 


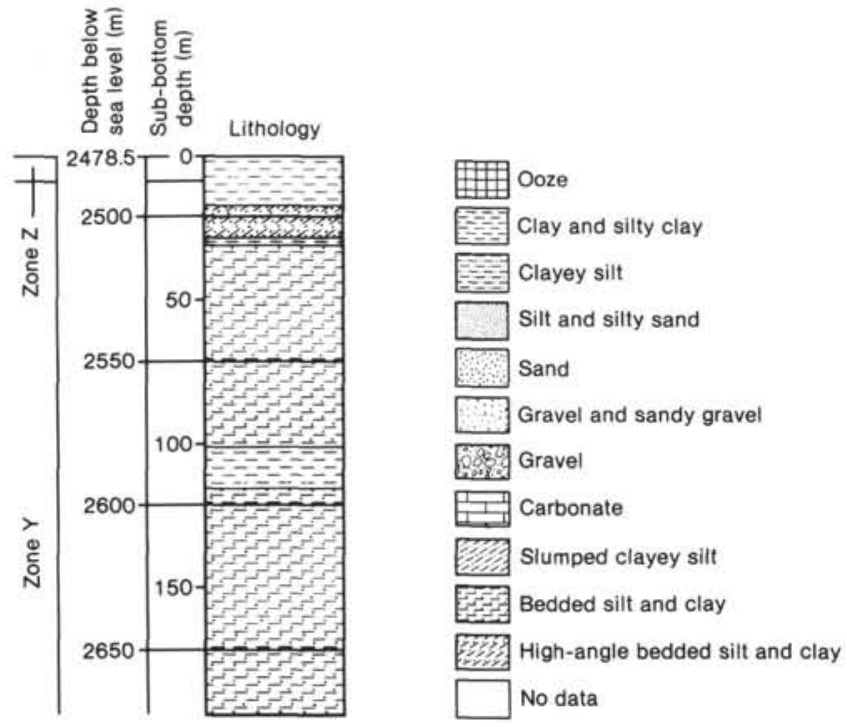

Figure 15. Site 617 , middle fan swale site (near channel overbank area). Generalized lithologic column, stratigraphic zonation, and depth $(\mathrm{m})$ below sea level and sub-bottom. Legend covers Figures 13-21, 24, and 25. (Modified after Bouma, Coleman, et al., 1984.)

the rotary drilling techniques. Initial calculations from unprocessed well-log data suggest that the drilled section contains less than $3 \%$ sand, about $24 \%$ silt, and $73 \%$ clay. Only a few, very thin, sand beds were observed.

Sites 623 and 624 on the upfan part of the lower fan are quite similar, the main difference being that the nearchannel site (623) contains more sand sections than Site 624 (Figs. 17 and 18). Cores from both these sites support the interpretation of channel switching, producing a lithologic record of vertical alternations of channel fill and overbank deposits. No systematic pattern or sedimentary sequence could be observed.

The two lower fan sites represent "sheet sand" deposits or "depositional lobes" (Figs. 19 and 20). Site 614 was drilled only to a depth of $150 \mathrm{~m}$ and did not penetrate sufficiently into the upper fan lobe to provide much data on its overall characteristics and comparison with ancient fan deposits. Site 615 (Fig. 20) penetrated the upper two fan lobes, Ericson Zone X interglacial sediments, and may have terminated in Ericson Zone W. Zone X sediments consist of a fining-upward, 29-m-thick calcareous unit of nannoplankton ooze with an upwarddecreasing percentage of foraminifers in its lower half. Available seismic data indicate that this zone is clearly delineated by acoustical reflectors and that the carbonate unit thickens to the northeast (see Stelting et al., this volume). Different interpretations have been suggested for the mode of emplacement of this unit, a thick debris flow deposit being the most likely candidate (see also Brooks et al., this volume).

Site 616 , located on the eastern margin of the youngest fan lobe, penetrated a disturbed mass, about $96 \mathrm{~m}$ thick, representing the "slump" described by Walker and Massingill (1970). Below the "slump deposits," two older fan lobes were penetrated that both show coarseningupward trends (Fig. 21). The relationships of these fan lobes to the area drilled on the middle fan are discussed

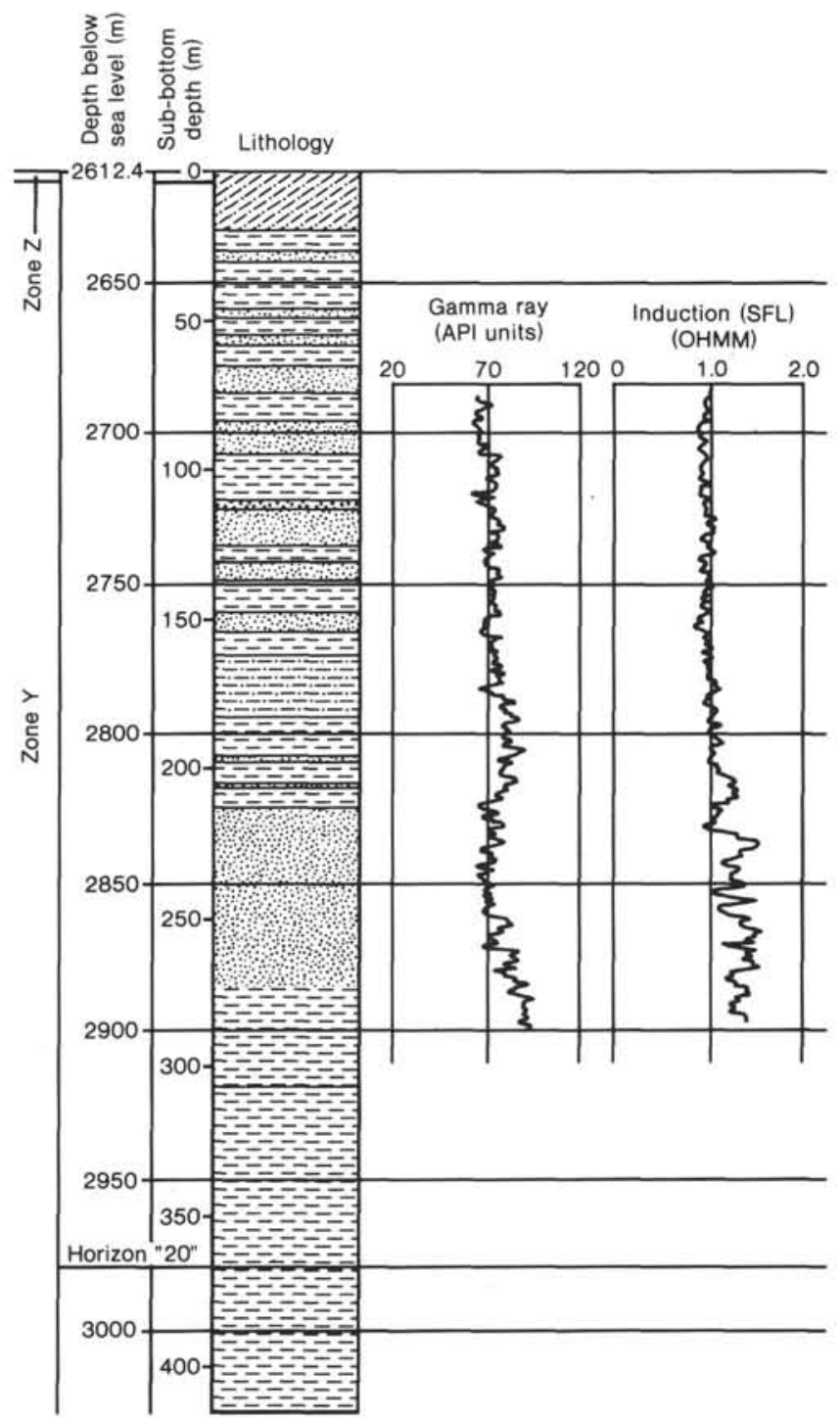

Figure 16. Site 620, middle fan overbank site. Generalized lithologic column, stratigraphic zonation, uncorrected gamma ray and induction $\log$ traces, and depth $(\mathrm{m})$ below sea level and sub-bottom. Seismic Horizon " 20 " is indicated. For legend see Figure 15. (Modified after Bouma, Coleman, et al., 1984.)

by Stelting et al. (this volume) in their contribution on seismic stratigraphy.

These generalized illustrations (Figs. 13-21) provide an overall picture of the drilling results on the Mississippi Fan and a schematic lithologic framework for the site chapters and the detailed chapters presented in this volume (see also Bouma, Coleman, and Meyer, 1984).

\section{INTRASLOPE BASINS}

The continental slope off Texas and Louisiana consists morphologically of hillocks and depressions (Fig. 22). This irregular topography is governed by a large number of diapirs of different sizes and shapes (Fig. 23) (Martin, 1984). Most of these diapirs are cored by salt of Louann age that was originally deposited during the Middle to Late Jurassic. Overlying the salt cores are fractured shales of early Tertiary age. These, in turn, are 


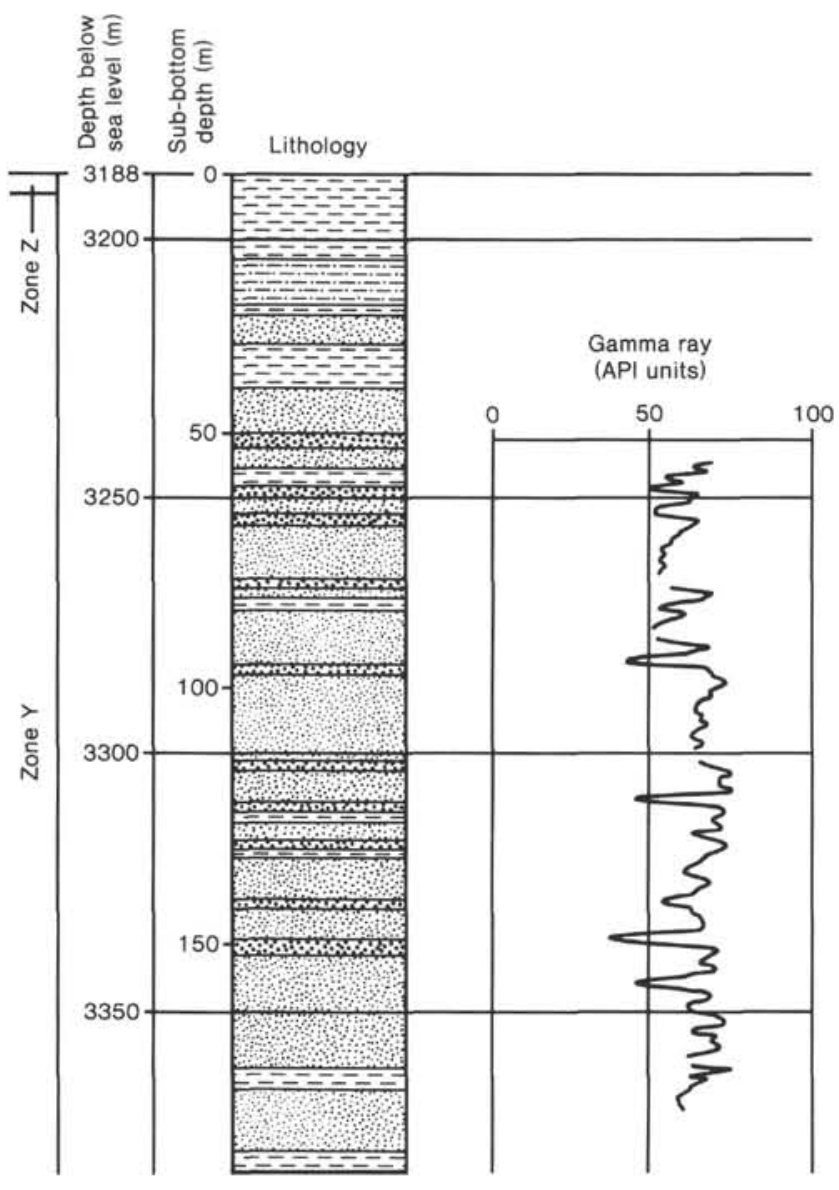

Figure 17. Site 623 , lower fan channel/levee complex. Generalized lithologic column, stratigraphic zonation, uncorrected gamma ray trace, and depth $(\mathrm{m})$ below sea level and sub-bottom. For legend see Figure 15. (Modified after Bouma, Coleman, et al., 1984.)

normally capped by younger Tertiary and Quaternary sediments (Lehner, 1969; Martin, 1978).

The depressions or intraslope basins, located between the topographically higher diapirs, also vary considerably in size and shape. Based on high-resolution seismic reflection profiles, water chemistry, salinity-temperaturedepth profiles, and short cores, these intraslope basins can be divided into three categories: (1) blocked-canyon basins, (2) interdomal basins, and (3) collapse basins (Martin and Bouma, 1978; Martin, 1980; Bouma, 1981, 1982; Bouma et al., 1980, 1981, 1983).

Blocked-canyon intraslope basins are formed from preexisting submarine canyons or channels that became blocked by upward moving diapirs that transformed the channel into one or more oblong basins. These channels are considered to have been the conduits for bottom transported sediment, sourced on the continental shelf and/ or upper slope. Some of these channels may have transported sediment across the slope provinces onto the rise where small coalescing fans can presently be found directly south of the Sigsbee Escarpment. The diapiric activity has not been constant through time but episodic and often out of synchronism with active sediment deposition. As a result, sediment transport by bottom-hugging mechanisms may have occurred unhindered for a while, after which blockage took place. A few examples of this type of intraslope basin have been investigated to date. These include Gyre Basin, Nomination Area, and Pigmy Basin (Bouma, 1981, 1982; Bouma et al., 1978, 1980, 1981; Feeley, 1982).

In blocked-canyon intraslope basins, high to medium resolution seismic-reflection profiles show vertical sequences that start with an acoustically (semi) transparent or chaotic zone which often onlaps onto the underlying sequence. That zone is overlain by discontinuous parallel reflectors, which are capped by a zone of more distinct and continuous parallel reflectors. This seismic facies sequence is thought to represent a fining-upward sequence starting with sandy or silty debris flow deposits and turbidites, followed by active mud deposition from turbidity currents, and overlain by pelagic and hemipelagic sediments. The history of this sequence is assumed to be related to sea-level variations from low stand through high stand.

Interdomal intraslope basins are interpreted to form when upward moving diapirs coalesce and surround an area, thereby closing it off from any bottom transport from the updip area. These isolated basins may have started as a sediment conduit but after being completely blocked they can receive only pelagic and hemipelagic sediments or material that slides down from the diapiric sides. Only one basin of this type has been studied in detail: Orca Basin (Trabant and Presley, 1978; Feeley, 1982). This basin is slightly abnormal in that it contains at its central bottom a layer of anoxic brine that is $200 \mathrm{~m}$ thick. Its chemical characteristics have made it a study target for chemical and stratigraphic investigations.

The third type of intraslope basins are the collapse basins. These are the smallest type and are found on top of most diapirs. They are formed either as the result of tensional collapse or from salt dissolution of the central diapiric core. These grabenlike features often are irregular in shape, show steep walls that may have steps, and receive only pelagic and hemipelagic sediments. East Breaks Basin and Carancahua Basin are the only ones over which detailed seismic surveys have been conducted (Feeley, 1982; Bouma et al., 1983).

Drilling at Site 618 in Orca Basin was terminated earlier than anticipated because of the thick slump mass incorporated within the Holocene which made it impossible to collect a good, continuous stratigraphic record (Fig. 24). Extensive sampling was done for chemical analyses and contributors have reported their findings in several chapters in this volume (e.g., Pflaum et al., Burke et al., Whelan et al., Requejo et al.).

Drilling at Site 619 in Pigmy Basin was very successful and provided good correlations between biostratigraphic, oxygen isotope, paleomagnetic, tephrachronologic, lithologic, and seismic studies. A number of chapters in this volume deal with these findings (e.g., Bouma, Stelting, et al., Requejo et al., Whelan et al., Pflaum et al., Williams and Kohl, Kohl, Ledbetter, King, Tieh et al.). Figure 25 shows a general lithologic column for the sediments recovered at Site 619. The seismic sequence, discussed earlier, can be related to the trends in the lithologic characteristics. The sediments show fining-upward 


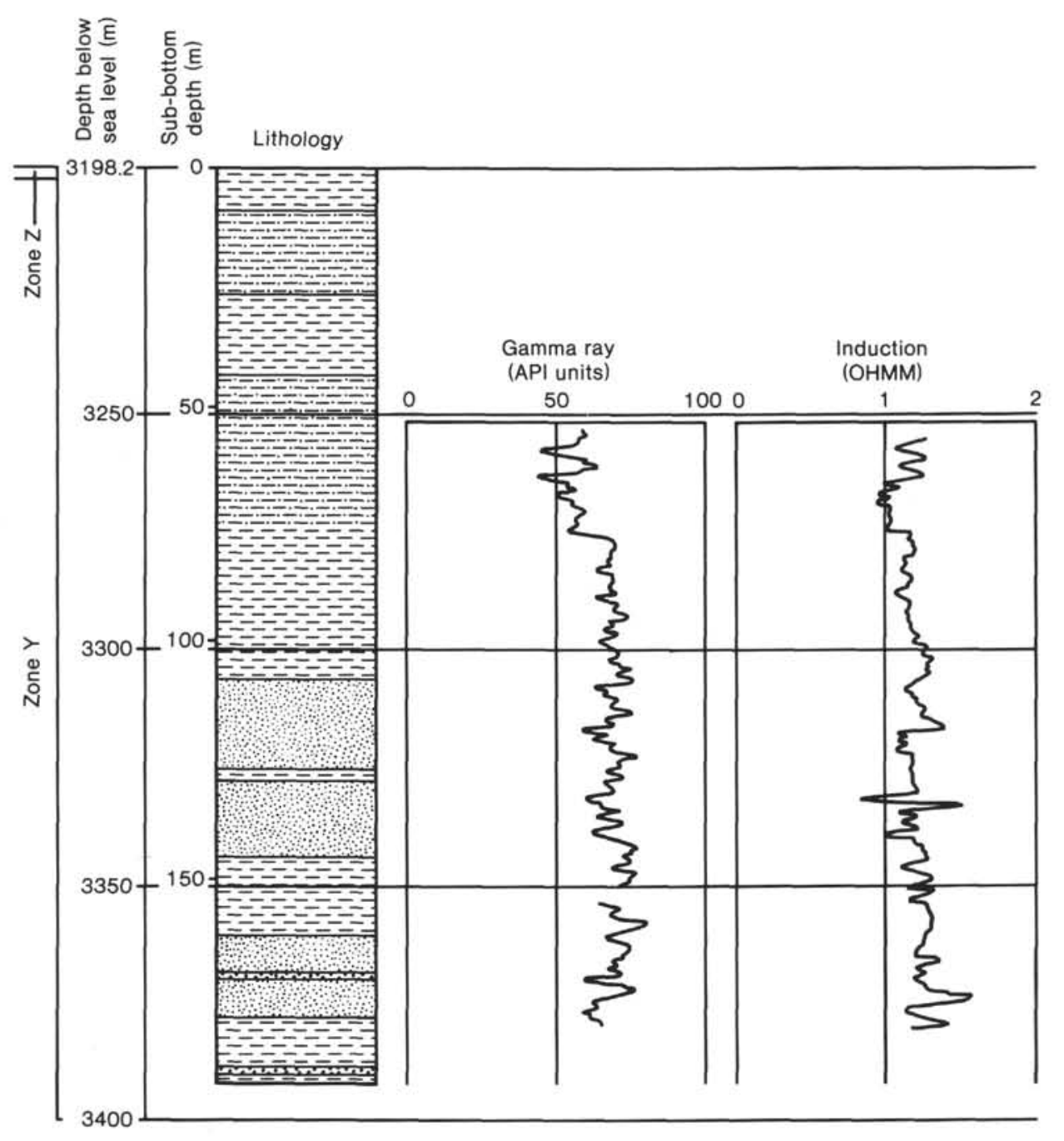

Figure 18. Site 624 , lower fan levee complex with thin channel fills. Generalized lithologic column, stratigraphic zonation, uncorrected gamma ray and induction log traces, and depth $(\mathrm{m})$ below sea level and sub-bottom. For legend see Figure 15. (Modified after Bouma, Coleman, et al., 1984.)

sequences from silty mud to mud without appreciable amounts of coarser sediment. Small amounts of biogenic methane were observed in Pigmy Basin below a depth of $90 \mathrm{~m}$.

\section{SUMMARY OF MAIN DRILLING RESULTS}

Leg 96 drilling on the Mississippi Fan and in the two intraslope basins produced some very important results, although not all of the drilling objectives could be obtained, specifically those that required a high degree of core recovery in sands. The main results are summarized below (see also Bouma, Coleman, et al., 1985). More detailed information on these and other findings can be found in the site chapters and in the specific chapters in the second part of this volume.

1. The Mississippi Fan consists of several fan lobes, each having an elongated shape. During the Pleistocene, a general migration of fan lobe deposition from west to east and toward deeper water took place.

2. A fan lobe is basically a channel-overbank complex that can be divided into four areas. (1) A canyon that is incised into the shelf and upper slope. It is likely formed by retrogressive slope failure. (2) The upper fan which terminates at the base of slope. It acts primarily as a conduit although some aggradation took place. It may contain some coarse material along its original bottom, especially in the lower part. The main fill is likely deposited in a passive mode and thus consists of finegrained sediments. (3) The aggradational middle fan which is convex in cross section and has a laterally migratory and aggradational channel running along its apex. (4) The aggradational lower fan which is characterized by several semiparallel channels of which only one was active at a given time. Near their terminus a channel may bifurcate and deposition of sheet sands took place.

3. The single sinuous channel on the middle fan is migratory and aggradational in nature and displays a general similarity to meandering fluvial systems. The channel fill shows a fining-upward sequence. The basal part of the channel fill is generally overlain by pebbly mud and sand. This coarse material coincides with the acoustic high-amplitude zone seen on seismic reflection 


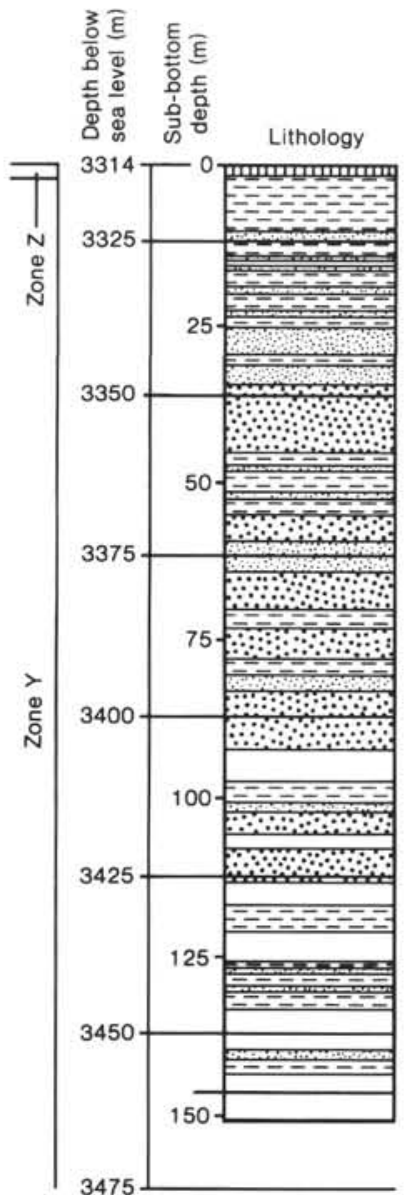

Figure 19. Site 614, lower fan sheet sand area. Generalized lithologic column, stratigraphic zonation, and depth $(\mathrm{m})$ below sea level and sub-bottom. For legend see Figure 15. (Modified after Bouma, Coleman, et al., 1984.)

profiles. Fauna found within the channel fill sediments is rare and poorly preserved; only reworked upper and middle neritic species were found.

4. The overbank deposits are much finer in grain size than the midfan channel fill deposits. Site 617 , located close to the channel in the region of ridge and swale topography, has more sand than Site 620 located $18 \mathrm{~km}$ away from the channel. The deposits at the latter site contain some indigenous fauna and have even less reworked shallow water species.

5. Transport of coarse sediment must have been primarily contained within the channel. The channel likely was not wider than 2 to $4 \mathrm{~km}$ and not deeper than 100 to $140 \mathrm{~m}$ during an active transport period in the area of Sites 621 and 622 . The sediment volumes must have been very large and the density flows thicker than the effective channel dimensions to account for the thick accumulation of overbank deposits.

6. The upfan area of the lower fan contains one distinct channel and a number of more or less parallel channelized traces. Drilling indicates vertical successions of channel-type fill of sand and finer material, well bedded levee-type deposits, and overbank sediments. The observation that only one channel was active at a given time cannot be proven but seems to be valid.

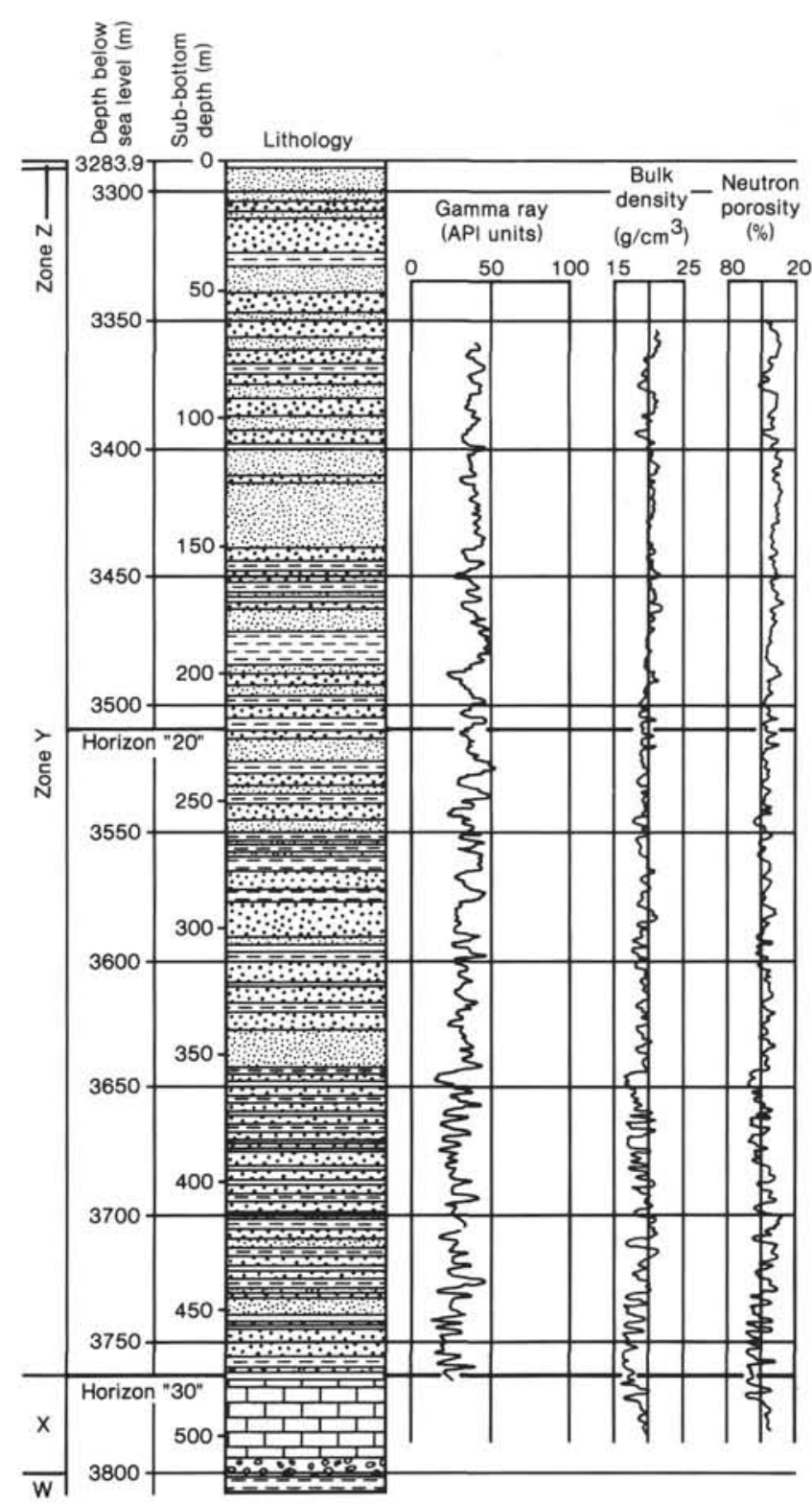

Figure 20. Site 615 , lower fan sheet sands near channel terminations. Generalized lithologic column, stratigraphic zonation, uncorrected gamma ray, bulk density, and neutron porosity traces, and depth (m) below sea level and sub-bottom. Seismic Horizons " 20 " and " 30 " are indicated. For legend see Figure 15. (Modified after Bouma, Coleman, et al., 1984.)

7. Significant amounts of sand, derived from a source area with a low sand/clay ratio, were moved across the fan to its distal area, a transport distance in excess of $600 \mathrm{~km}$.

8. At Site 615 , we drilled through the upper two fan lobes, both of upper Wisconsin age. The upper fan lobe has a net sand content of $41 \%$ based on unprocessed gamma ray logs, the lower has $65 \%$ net sand. Each sequence gives the general impression of coarsening upward from mud to silt, followed by bedded sand, and topped by a thinner fining-upward sequence.

9. The typically low recovery of sands and fluidization of most of those recovered makes comparison with ancient turbidites impossible, especially when searching 


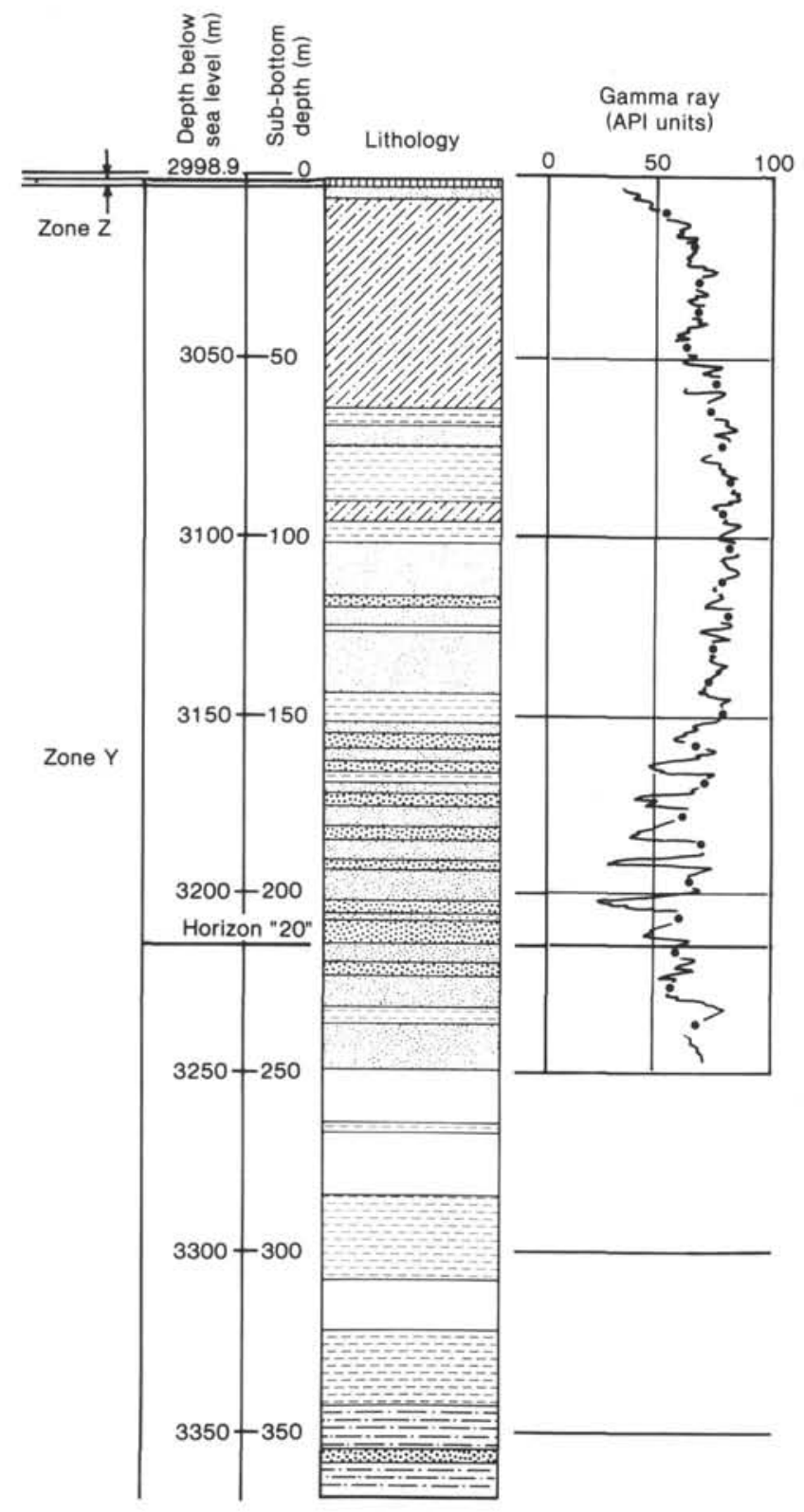

Figure 21. Site 616, middle fan "slump" site. Generalized lithologic column, stratigraphic zonation, uncorrected gamma ray trace obtained through the pipe (dots are pipe joints), and depth (m) below sea level and sub-bottom. For legend see Figure 15. (Modified after Bouma, Coleman, et al., 1984.)

for sequences in sedimentary structures, grain size trends, depositional lobes, and compensation cycles.

10. A 29-m-thick carbonate was recovered at Site 615, underlying the sands discussed under point 8 above. The carbonate consists of a fining-upward sequence from a foraminifer-rich nannoplankton ooze with chalk fragments at the bottom to a fine nannoplankton ooze at the top. Shallow water benthic foraminifers were observed. Based on sparse seismic data we conclude it to be the deposit of a debris flow that came from the Florida Platform-Escarpment to the northeast (Brooks et al., this volume).

11. Drilling at Site 616 in the slump area, as interpreted by Walker and Massingill (1970), established the

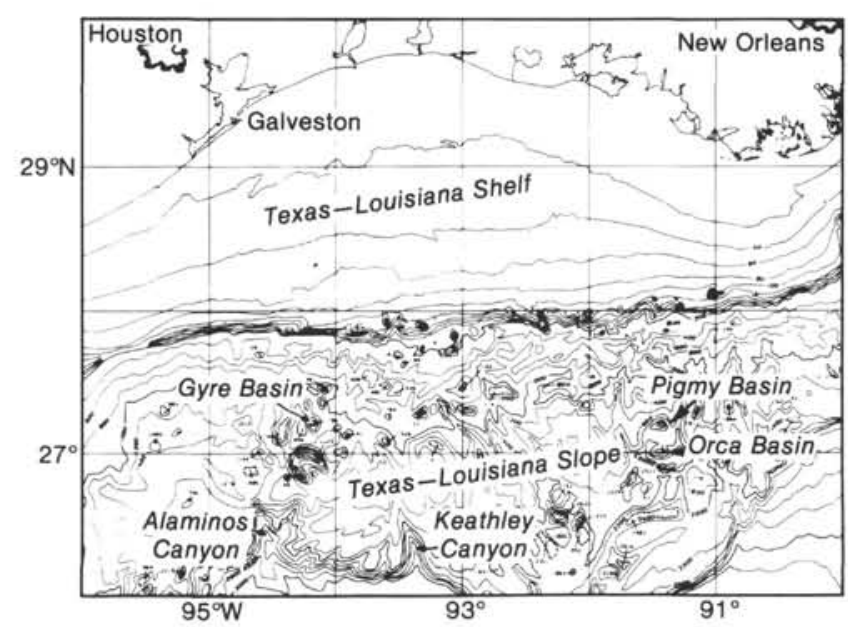

Figure 22. Generalized bathymetry of the Texas-Louisiana continental slope with the locations of the intraslope basins mentioned in the text.

thickness of the "slump" feature to be $95-105 \mathrm{~m}$. It consists of individual packages ranging from a few meters to over $10 \mathrm{~m}$ in thickness, separated by heavily disturbed zones or by normally horizontally bedded fine-grained sediment. Each individual package shows dipping, parallel bedding. No systematic increase or decrease in dip could be observed in a downhole direction. We interpret this "slump" to consist of individual slides that may have derived from the upper slope to the north.

12. Sedimentation rates are extremely high on the Mississippi Fan for the late Wisconsin deposits. For the youngest fan lobe, the sedimentation rates on the middle fan are nearly $12 \mathrm{~m} / 1000 \mathrm{yr}$. in both the channel fill and the overbank deposits. On the lower fan, the rates range from 5 to $6 \mathrm{~m} / 1000 \mathrm{yr}$. These are average values for nondecompacted sediments.

13. The Mississippi Fan sediments were normally void of visible gas although X-ray radiographs show some gas expansion cracks (Coleman, Bouma, et al., this volume).

14. All sediments are underconsolidated to slightly underconsolidated (Byrant, Wetzel, Taylor, and Sweet, this volume) and many disturbed sections were observed in the cores that may be natural rather than the result of drilling.

15. Site 618 in Orca Basin did not answer the objectives because of the presence of a slump: stratigraphically downhole, we went from Holocene to Pleistocene slump sediments and then back into Holocene deposits underlain by Pleistocene material. Biogenic methane was present at all depths at levels high enough to produce gas hydrates between 20 and $40 \mathrm{~m}$ sub-bottom (Pflaum et al., this volume).

16. Site 619 in Pigmy Basin provided a good biostratigraphic record for the late Neogene (Kohl, this volume). Samples for magnetic stratigraphy were collected (King, this volume) and a volcanic ash bed was found $(84,000$ yr.; Ledbetter, this volume). These three sets of data, together with oxygen-isotope values (Williams and Kohl, this volume) provide an excellent downhole stratigraphic record. 


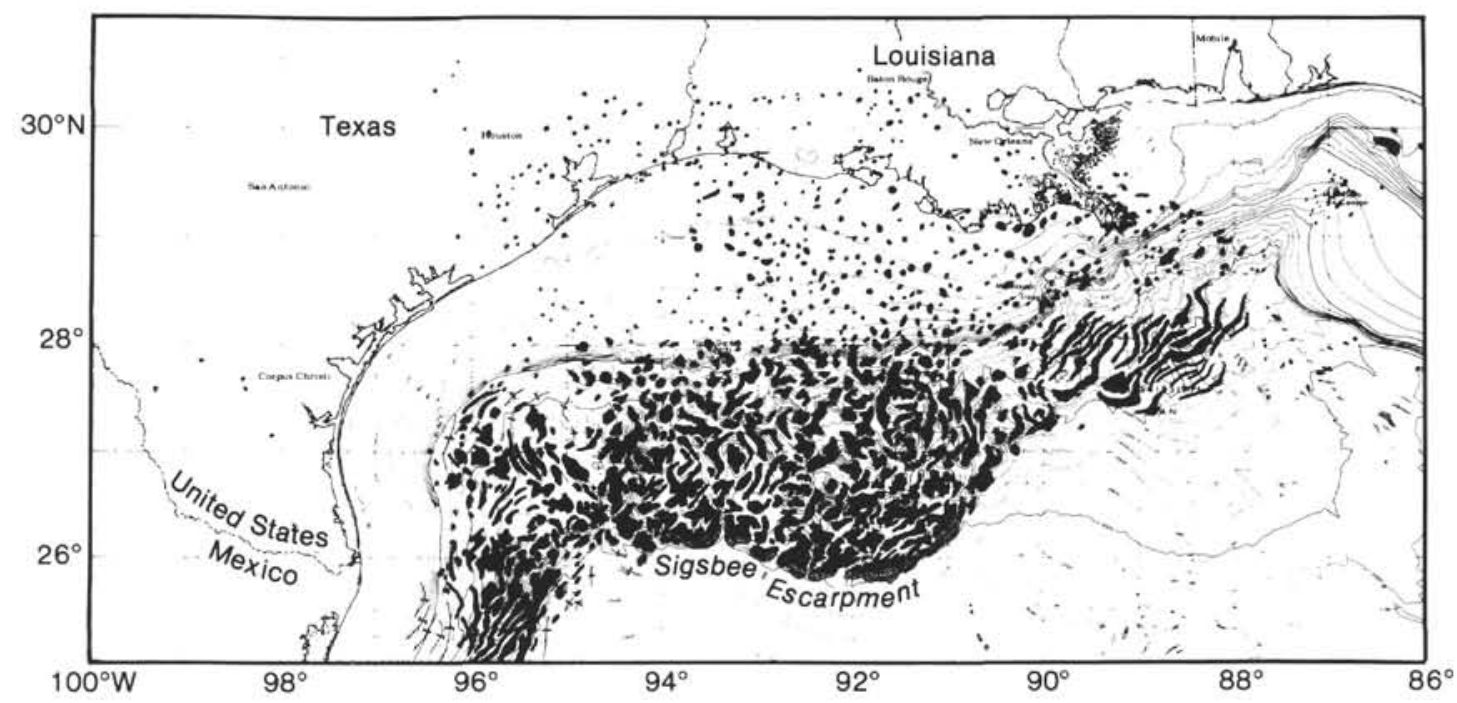

Figure 23. Outline of diapirs at $1 \mathrm{~s}$ below the mudline (sea-bottom) for the Texas-Louisiana continental margin. The gray patterned area along the southward bulge of the Sigsbee Escarpment indicates the zone where diapiric salt "flowed" nearly horizontally near the seabottom to the south forming the escarpment. (After Martin, 1980.)

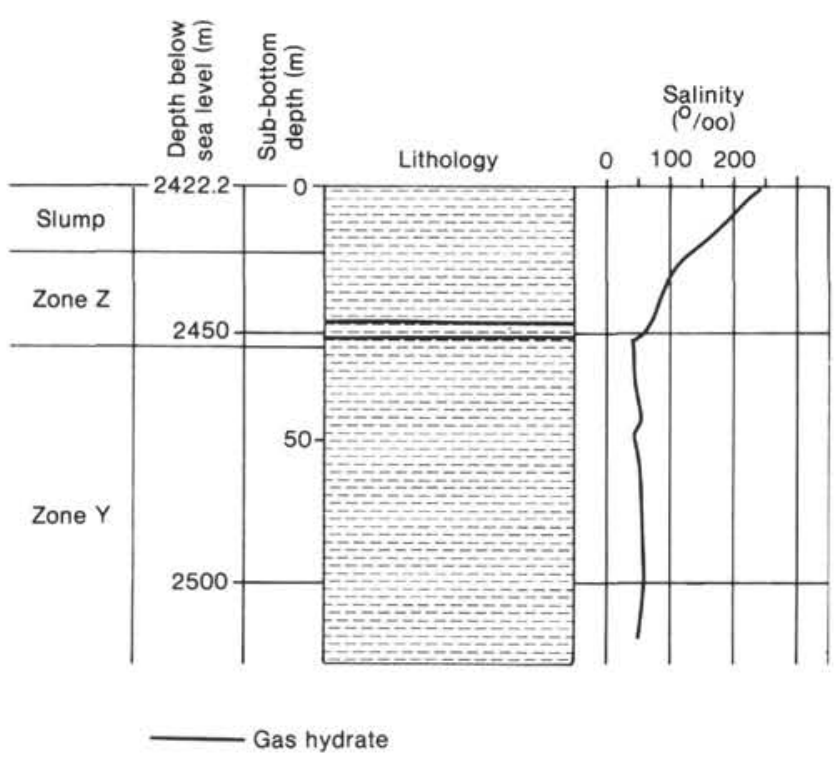

Figure 24. Site 618, Orca Basin, interdomal basin on the continental slope off Louisiana. Generalized lithologic column, stratigraphic zonation, salinity, and depth $(\mathrm{m})$ below sea level and sub-bottom. For legend see Figure 15.

17. No sand of any significance was encountered in Pigmy Basin. However, a tie between lithologies and seismic facies could be made with fining-upward sequences observed in the recovered sediments (Bouma, Stelting, et al., this volume).

18. Small amounts of biogenic methane were observed in Pigmy Basin below a depth of $90 \mathrm{~m}$.

\section{SCIENTIFIC IMPORTANCE OF LEG 96}

Devoting one leg of the DSDP to the drilling of a submarine fan resulted in very valuable scientific information. Our results provide the geological community with interpretations that should be of value to future studies of modern deep-sea fans and their rock equivalents. The following general statements document many facts and speculations derived from Leg 96 results. These results, with some or major modifications, can have applicability to other deep-sea fans, although some of the published speculations cannot be proven until similar drilling programs provide proof:

1. The Mississippi Fan is the first modern submarine fan to be drilled systematically, providing multiple cored locations through at least one sea-level cycle.

2. The entire sediment volume that makes up the fan is composed of individual fan lobe systems. By analogy with the youngest fan lobe drilled on Leg 96, each fan lobe corresponds to a sea-level cycle.

3. Sea-level variations have a significant influence on the delivery of sediment to the deep-water fan system, specifically in passive margin settings. Sedimentation rates were extremely high during the low sea level period that was drilled during Leg 96 . The bulk of these sediments consist of resedimented material derived from the adjacent shelf and upper continental slope. During the most recent high sea level period, sedimentation on the submarine fan was dominated by hemipelagic and pelagic material that was deposited at a much slower rate.

4. High sedimentation rates during low sea level stands result in underconsolidated, overpressured deposits.

5. A single sinuous, migratory, and aggradational channel transverses nearly the entire length of the fan lobe. It generally decreases in size and sinuosity in the downfan direction. Near the distal end, channel positions were ephemeral as the channel shifted frequently during the construction of the fan lobe.

6. Seismically, the lower part of the fill of the migratory, aggradational channel on the middle fan is characterized by a high-amplitude reflection zone representing channel lag deposits. This zone climbs stratigraphically and may have lateral continuity. 


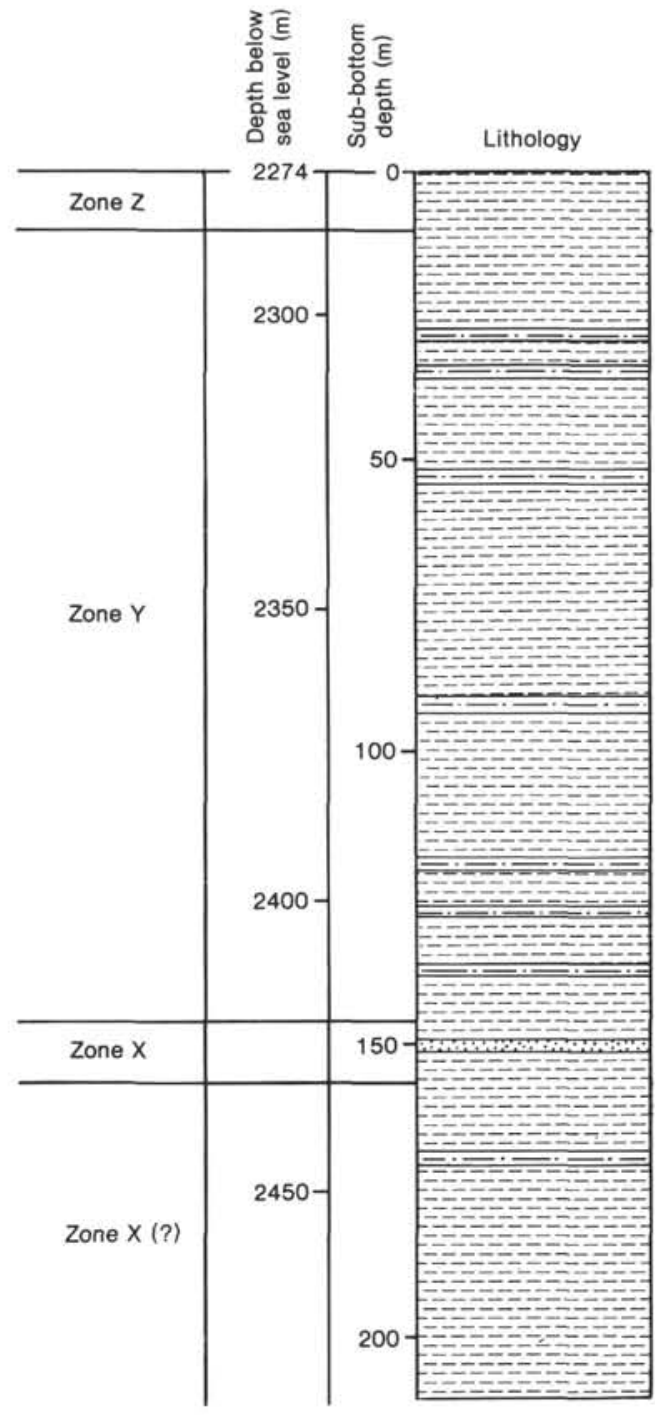

Figure 25. Site 619, Pigmy Basin, blocked-canyon basin on the continental slope off Louisiana. Generalized lithologic column, stratigraphic zonation, and depth (m) below sea level and sub-bottom. For legend see Figure 15.

7. The bulk of the sediments on a passive margin fan are composed of overbank deposits characterized by thinbedded, fine-grained turbidites. Sands are associated with the midfan channel complex and with the sheet sand deposits near the distal end of a fan lobe.

8. Large- and small-scale mass-movement processes play a major role in the development of the entire fan lobe, and seem to prevail in the middle region and likely in the upper fan.

9. In a submarine fan with high sediment accumulation rates, planktonic and benthic fauna are scarce within sediments deposited during low sea level, but are slightly more abundant in the deposits that accumulated during high sea level periods.

10. The distinct vertical seismic sequence observed in blocked-canyon intraslope basins, such as Pigmy Basin, can be related to the lithologic differences observed in the cores. However, textural differences were much smaller than anticipated, as seismic zones interpreted as sand prior to the drilling proved to be silty mud.

\section{REFERENCES}

Barlow, J. A., 1966. Deep submarine channel in upper Miocene, Orange County, California. J. Sediment. Petrol., 36:700-705.

Bates, C. C., 1953. Rational theory of delta formation. Am. Assoc. Pet. Geol. Bull., 37:2119-2162.

Bellaiche, G., Droz, L., Aloisi, J.-C., Bouye, C., Got, H., Monaco, A., Maldonado, A., Serra-Raventos, J., and Mirabile, L., 1981. The Ebro and the Rhone deep-sea fans: first comparative study. Mar. Geol., 43:M75-M85.

Bouma, A. H., 1981. Depositional sequences in clastic continental slope deposits, Gulf of Mexico. Geo-Mar. Lett., 1:115-121. 1982. Intraslope basins in northwest Gulf of Mexico: Key to ancient submarine canyons and fans. In Watkins, J. S., and Drake, C. L. (Eds.), Geologic Evolution of Continental Margins. Am. Assoc. Pet. Geol. Mem., 43:567-581.

Bouma, A. H., and Brouwer, A., (Eds.), 1964. Turbidites. Developments in Sedimentology 3: Amsterdam (Elsevier).

Bouma, A. H., Coleman, J. M., and DSDP Leg 96 Shipboard Scientists, 1985. Mississippi Fan: Leg 96 program and principal results. In Bouma, A. H., Normark, W. R., and Barnes, N. E. (Eds.), Submarine Fans and Related Turbidite Systems. Frontiers in Sedimentary Geology 1: New York (Springer-Verlag) pp. 247-252.

Bouma, A. H., Coleman, J. M., and Leg 96 Scientific Crew, 1984. Seismic stratigraphy and sedimentology of Leg 96 drilling on the Mississippi Fan. Fifth Ann. Res. Conf. Gulf Coast Section Soc. Economic Paleontol. Mineral. Found., Dec. 2-5, 1984, Austin, Texas. Characteristics of Gulf Basin Deep-Water Sediments and their Exploration Potential, Program and Abstracts, pp. 11-22.

Bouma, A. H., Coleman, J. M., and Meyer, A. A., 1984. Challenger drills Mississippi Fan. Geotimes, 29(7):15-18.

Bouma, A. H., Feeley, M. H., Kindinger, J. L., Stelting, C. E., and Hilde, T. W. C., 1981. Seismic stratigraphic characteristics of upper Louisiana continental slope and area east of Green Canyon. Proc. Offshore Technol. Conf., Houston, TX, 4098:283-291.

Bouma, A. H., Martin, R. G., and Bryant, W. R., 1980. Shallow structure upper continental slope, Central Gulf of Mexico. Proc. Offshore Technol. Conf., Houston, Tx, 3913:583-592.

Bouma, A. H., Normark, W. R., and Barnes, N. E. (Eds.), 1985. Submarine Fans and Related Turbidite Systems. Frontiers in Sedimentary Geology 1: New York (Springer-Verlag).

Bouma, A. H., Smith, L. B., Sidner, B. R., and McKee, T. R., 1978. Intraslope basins in northwest Gulf of Mexico. In Bouma, A. H., Moore, G. T., and Coleman, J. M. (Eds.), Framework, Facies, and Oil-Trapping Characteristics of the Upper Continental Margin. Am. Assoc. Pet. Geol. Stud. Geol., 7:289-302.

Bouma, A. H., Stelting, C. E., and Coleman, J. M., 1985. Mississippi Fan, Gulf of Mexico. In Bouma, A. H., Normark, W. R., and Barnes, N. E. (Eds.), Submarine Fans and Related Turbidite Systems. Frontiers in Sedimentary Geology 1: New York (SpringerVerlag), pp. 143-150.

Bouma, A. H., Stelting, C. E., and Feeley, 1983. High-resolution seismic reflection profiles. In Bally, A. W. (Ed.), Seismic Expression of Structural Styles, A Picture and Work Atlas. Am. Assoc. Pet. Geol. Stud. Geol., 15:1.2.1-1-1.2.1-23.

Coleman, J. M., Prior, D. B., and Lindsay, J. F., 1983. Deltaic influences on shelf edge instability processes. In Stanley, D. J., and Moore, G. T. (Eds.), The Shelf Break, Critical Interface on Continental Margins. Soc. Econ. Paleontol. Mineral. Spec. Publ., 33: 121-137.

Cremer, M., 1983. Approches sedimentologique et geophysique des accumulations turbiditiques; l'Eventail profond du Cap-Ferret (Golfe de Gascogne), la serie des Gres d'Annot (Alpes de Haute Provence) [Ph.D. thesis]. Univ. Bordeaux, France.

Damuth, J. E., Kolla, V., Flood, R, D., Kowsmann, R., Monteiro, M. C., Gorina, M. A., Palma, J. O., and Belderson, R., 1983. Distributary channel meandering and bifurcation patterns on the Amazon deep-sea fan as revealed by long-range, side-scan sonar (GLORIA). Geology, 11:94-98. 
Ericson, D. B., and Wollin, G., 1968. Pleistocene climates and chronology in deep-sea sediments. Science, 162:1227-1234.

Feeley, M. H., 1982. Structural and depositional relationships of intraslope basins, northern Gulf of Mexico [M.S. thesis]. Texas A\&M University, College Station Texas.

Ferebee, T. W., and Bryant, W. R., 1979. Sedimentation in the Mississippi Trough. Tex. A\&M Univ. College Geosci. Rept., 79-4-T:1-178.

Fisk, H. N., and McFarlan, E., Jr., 1955. Late Quaternary deposition of the Mississippi River. In Poldervaart, A. (Ed.), Crust of the Earth. Geol. Soc. Am. Spec. Pap., 62:279-302.

Garrison, L. E., Kenyon, N. H., and Bouma, A. H., 1982. Channel systems and lobe construction of the eastern Mississippi Fan lobe. Geo-Mar. Lett., 2:279-302.

Gealy, B. L., 1955. Topography of the continental slope, northwest Gulf of Mexico. Geol. Soc. Am. Bull., 66:203-227.

Gorsline, D. S., and Emery, K. O., 1959. Turbidity-current deposits in San Pedro and Santa Monica basins off Southern California. Geol. Soc, Am. Bull., 70:279-290.

Hand, B. M., and Emery, K. O., 1964. Turbidites and topography off north end of San Diego Trough, California. J. Geol., 72:526-542.

Kastens, K. A., and Shor, A. N., 1985. Depositional processes of a meandering channel on the Mississippi Fan. Am. Assoc. Pet. Geol. Bull., 69:190-202.

Kuenen, Ph.H., and Migliorini, C. J., 1951. Turbidity currents as a cause of graded bedding. J. Geol., 58:91-127.

Lehner, P., 1969. Salt tectonics and Pleistocene stratigraphy on continental slope of northern Gulf of Mexico. Am. Assoc. Pet. Geol. Bull., 53:2431-2479.

Martin, R. G., 1978. Geologic framework of northern and eastern continental margins, Gulf of Mexico. In Bouma, A. H., Moore, G. T., and Coleman, J. M. (Eds.), Beyond the Shelf Break. Am. Assoc. Pet. Geol. Mar. Geol. Comm. Short Course: A1-A28. 1980. Distribution of salt structures in Gulf of Mexico Region; map and descriptive text. U.S. Geol. Surv. Miss. Field Stud. Map, MF-1213, 2 sheets, 8 p.

1984. Diapiric trends in the deep-water Gulf Basin. Fifth Ann. Res. Conf. Gulf Coast Section Soc. Econ. Paleon. Mineral. Found., Dec. 2-5, 1984, Austin, Texas. Characteristics of Gulf Basin Deep-Water Sediments and Their Exploration Potential, Program and Abstracts, pp. 60-62.

Martin, R. G., and Bouma, A. H., 1978. Physiography of Gulf of Mexico. In Bouma, A. H., Moore, G. T., and Coleman, J. M. (Eds.), Framework, Facies, and Oil-Trapping Characteristics of the Upper Continental Margin. Am. Assoc. Pet. Geol. Stud. Geol., 7: 3-19.

Menard, H. W., 1955. Deep-sea channels, topography, and sedimentation. Am. Assoc. Pet. Geol. Bull., 39:236-255.

Moore, G. T., Starke, G. W., Bonham, L. C., and Woodbury, H. O., 1978. Mississippi Fan-Gulf of Mexico-physiography, stratigraphy, and sedimentational patterns. In Bouma, A. H., Moore, G. T., and Coleman, J. M. (Eds.), Framework, Facies, and Oil-Trapping Characteristics of the Upper Continental Margin. Am. Assoc. Pet. Geol. Stud. Geol., 7:155-191.

Moore, G. T., Woodbury, H. O., Worzel, J. L., Watkins, J. S., and Starke, G. W., 1979. Investigations of the Mississippi Fan. Gulf of Mexico, Am. Assoc. Pet. Geol. Mem., 29:393-402.

Mutti, E., and Ricci Lucchi, F., 1972. Le torbiditi dell Appennino settentrionale; introduzione all'analisi di facies. Mem. Soc. Geol. Italiana, 11:161-199.

Normark, W. R., 1970. Growth pattern of deep-sea fans. Am. Assoc. Pet. Geol. Bull., 54:2170-2195.

, 1978. Fan valleys, channels and depositional lobes on modern submarine fans: characteristics for recognition of sandy turbidite environments. Am. Assoc. Pet. Geol. Bull., 62:912-931.
1980. Modern and ancient submarine fans: reply. Am. Assoc. Pet. Geol. Bull., 62:1108-1112.

Normark, W. R., Mutti, E., and Bouma, A. H. (Eds.), 1983/84. Submarine clastic systems, deep-sea fans and related turbidite facies. Geo-Mar. Lett., 3:53-224.

O'Connell, S., Stelting, C. E., Bouma, A. H., Coleman, J. M., Cremer, M., Droz, L., Meyer-Wright, A. A., Normark, W. R., Pickering, K. T., Stow, D. A. V., and DSDP Leg 96 Shipboard Scientists, 1985. Drilling results on the lower Mississippi Fan. In Bouma, A. H., Normark, W. R., and Barnes, N. E. (Eds.), Submarine Fans and Related Turbidite Systems. Frontiers in Sedimentary Geology 1: New York (Springer-Verlag), pp. 291-298.

Phleger, F. B., 1955. Foraminiferal faunas in cores offshore from the Mississippi Delta. Pap. Mar. Biol. Oceanogr. Deep-Sea Res., Suppl., 3:45-57.

Shanmugam, G., and Moiola, R. J., 1982. Eustatic control of turbidites and winnowed turbidites. Geology, 10:231-235.

Shepard, F. P., 1937. Salt domes related to Mississippi submarine trough. Geol. Soc. Am. Bull., 48:1354-1361. Row).

Shepard, F. P., and Dill, R. F., 1966. Submarine Canyons and other Sea Valleys: Chicago (Rand McNally and Co.).

Shepard, F. P., and Marshall, N. F., 1969. Currents in La Jolla and Scripps submarine canyons. Science, 165:177-178.

Stelting, C. E., and DSDP Leg 96 Shipboard Scientists, 1985. Migratory characteristics of a midfan meander belt, Mississippi Fan. In Bouma, A. H., Normark, W. R., and Barnes, N. E. (Eds.), Submarine Fans and Related Turbidite Systems. Frontiers in Sedimentary Geology 1: New York (Springer-Verlag), pp. 283-290.

Stelting, C. E., Pickering, K. T., Bouma, A. H., Coleman, J. M., Cremer, M., Droz, L., Normark, W. R., O'Connell, S., Stow, D. A. V., Wright-Meyer, A. A., and DSDP Leg 96 Shipboard Scientists, 1985. Drilling results on the middle Mississippi Fan. In Bouma, A. H., Normark. W. R., and Barnes, N. E. (Eds.), Submarine Fans and Related Turbidite Systems. Frontiers in Sedimentary Geology 1: New York (Springer-Verlag), pp. 275-282.

Stuart, C. J., and Caughey, C. A., 1976. Form and composition of the Mississippi Fan. Trans. Gulf. Coast Assoc. Geol. Soc., 26:333-343.

Sullwold, H. H., 1960. Tarzana Fan, deep submarine fan of late Miocene age, Los Angeles County, California. Am. Assoc. Pet. Geol. Bull., 44:433-457.

Trabant, P. K., and Presley, B. J., 1978. Orca Basin, anoxic depression on the continental slope, northwest Gulf of Mexico. In Bouma, A. H., Moore, G. T., and Coleman, J. M. (Eds.), Framework, Facies, and Oil-Trapping Characteristics of the Upper Continental Margin. Am. Assoc. Pet. Geol. Stud. Geol., 7:303-311.

Walker, J. R., and Massingill, J. V., 1970. Slump features on the Mississippi Fan, northeastern Gulf of Mexico. Geol. Soc. Am. Bull., 81:3101-3108.

Walker, R. G., 1978. Deep-water sandstone facies and ancient submarine fans: models for exploration for stratigraphic traps. Am. Assoc. Pet. Geol. Bull., 62:932-966.

, 1980. Modern and ancient submarine fans: reply. Am. Assoc. Pet. Geol. Bull., 64:1101-1108.

Walker, R. G., and Mutti, E., 1973. Turbidite facies and facies associations. In Middleton, G. V., and Bouma, A. H. (Eds.), Turbidites and Deep Water Sedimentation. Soc. Econ. Paleontol. Mineral., Pacific Section Syllabus, pp. 119-158.

Date of Initial Receipt: 23 January 1985 Date of Acceptance: 26 June 1985 